\title{
Impacts of Extreme Weather Events on Hydromorphology of UK Rivers
}

\section{Aşırı Hava Olaylarının Birleşik Krallık Nehir Hidromorfolojisine Etkisi}

\author{
Seher Gulcin Yilmaz ${ }^{1,2 *}$, Abdul Chaudhary ${ }^{2}$, Rakesh Kanda ${ }^{2}$ \\ ${ }^{1}$ Ministry of Agriculture and Forestry, General Directorate of Water Management, 06510, Ankara, \\ Turkey \\ sehergulcin.yilmaz@tarimorman.gov.tr (https://orcid.org/0000-0002-2443-8862) \\ ${ }^{2}$ Institute of Environment, Health and Societies, Brunel University London, Uxbridge, UB8 3PH, \\ $U K$ \\ abdul.chaudhary@brunel.ac.uk (https://orcid.org/0000-0001-9438-0857), \\ rakesh.kanda@brunel.ac.uk (https://orcid.org/0000-0002-5427-3982) \\ Received Date: 01.11.2020, Accepted Date: 05.01.2021
}

\begin{abstract}
In this study, we assessed the effects of extreme weather events on Hydro-morphological Quality Elements in rivers of the United Kingdom alongside other pressures that will provide significant challenges for the implementation of the Water Framework Directive in the UK in terms of costeffectiveness and sustainability. While observed meteorological data and river data sets were used for assessing changes in river systems and weather patterns, for future assessments, UK Climate Projections 2018 data was used. The studies in the literature have shown that during periods of extreme events, the river hydro-morphology is affected especially in terms of river flows, sediments and riparian zones such as draughts, and intense and heavy rainfall leading to reduced or exceptionally high flow respectively. Reduced flows can lead to the loss of habitat of aquatic organisms and an increase in fish deaths. Whilst increased river flows lead to changes of the hydro-morphology of rivers including changes to sediment dynamics and channels, rivers are also under negative effects of anthropogenic hydro-morphological pressures such as building dams and water abstractions. Furthermore, changes in river hydro-morphology can cause other problems such as increasing water temperature and decreasing dissolved oxygen, and thereby degrading Biological Quality Elements and Physico-Chemical Quality Elements. To deal with and mitigate these problems, a holistic view of water policy that considers climate change projections, reduces water demand, changes agricultural and urban land use practices, improves water availability and quality is required.
\end{abstract}

Keywords: Extreme weather events, climate change, water framework directive, ecological quality status, river hydro-morphology

\section{$\ddot{O} z$}

Bu çalışmada, Birleşik Krallık'taki aşırı hava olaylarının nehirlerdeki Hidro-morfolojik Kalite Elementleri üzerindeki etkileri, Su Çerçeve Direktif'i uygulamasında sorunlara yol açabilecek diğer baskılarla birlikte değerlendirilmiştir. Nehir sistemi ve hava olaylarındaki değişiklikleri değerlendirmek için gözlemlenen meteorolojik ve nehir veri setleri kullanılırken, gelecek değerlendirmeler için Birleşik Krallık İklim Projeksiyonları 2018 verileri kullanılmıştır. Literatürdeki

\footnotetext{
${ }^{*}$ Corresponding author
} 
çalışmalarda aşırı hava olayların olduğu dönemlerde nehir hidro-morfolojisinin özellikle nehir akışları, sedimentleri ve nehir kıyı bölgeleri açısından etkilendiği bulunmuştur. Azalan akışlar, sudaki organizmaların yaşam alanlarının kaybına ve balık ölümlerinin artmasına neden olabilir. Artan nehir akışları, sediment dinamiği ve kanallarındaki değiş̧iklikler de dahil olmak üzere nehirlerin hidromorfolojisinde değişikliklere yol açarken, nehirler, bina barajları ve su soyutlamaları gibi aktiviteler de dahil olmak üzere antropojenik hidro-morfolojik basınçların olumsuz etkileri altındadır. Buna ek olarak, nehir hidro-morfolojisindeki değişikler su sıcaklığını arttıran ve çözünmüş oksijen miktarını azaltan başka problemlere sebep olabilir ve böylece Biyolojik Kalite Elementleri ve Fiziko-Kimyasal Kalite Elementlerini indirgeyebilir. Birleşik Krallık'ta aşırı olayların yoğunluğunun ve sıklığının artması, Su Çerçeve Direktifi'nin maliyet etkinliği ve sürdürülebilirlik açısından uygulanmasında zorluklara neden olacağına hiç şüphe yoktur. Bu sorunlarla başa çıkmak ve bunları azaltmak için, iklim değişikliği projeksiyonlarını dikkate alan, su talebini azaltan, suyun mevcudiyetini ve kalitesini iyileştiren, tarımsal ve kentsel arazi kullanım uygulamalarını değiştiren bütüncül bir su politikası gereklidir.

Anahtar kelimeler: Aşırı hava olayları, iklim değişikliği, su çerçeve direktifi, ekolojik kalite durumu, nehir hidro-morfolojis

\section{Introduction}

Fossil fuel consumption has increased very substantially since the Industrial Revolution starting in the middle of $18^{\text {th }}$ century England. In 1750, Great Britain produced about 5.2 million tons of coal per year, and by 1850, it was producing 62 million tonnes per year. Global fossil-fuel consumption has also increased exponentially. During the $20^{\text {th }}$ century, there was more than a 1300 -fold increase in the use of fossil fuels. Burning coal produces about 15 billion tonnes of carbon dioxide $\left(\mathrm{CO}_{2}\right)$ each year around the world at the present time. Coal still accounts for about a third of the world's fossil energy consumption. Fossil fuels (coal, natural gas, and oil) are the primary source of air pollution, emitting a range of pollutants to the atmosphere including $\mathrm{CO}_{2}$, Nitric Oxide $\left(\mathrm{NO}_{\mathrm{x}}\right)$, Sulfur Oxides $\left(\mathrm{SO}_{\mathrm{x}}\right)$ and other greenhouse gases. Therefore, the use of fossil fuels as the world's primary energy source contributes to the many environmental problems being observed today. In particular, greenhouse gas emissions have increased the greenhouse effect and are the major cause of climate change (Intergovernmental Panel on Climate Change [IPCC], 2014).

One of the unexpected problems that climate change causes is extreme weather events (Ren et al., 2018). The frequency, intensity and duration of extreme events are also changing due to many human factors, such as the growing global population which has increased from 670 million people at the start of the industrial revolution to over 6.7 billion (a 10 fold increase); there has also been an increase in urbanisation and infrastructure across the world. Changes in extreme events can be observed in some statistical parameters such as mean and variance of events. In addition to climate change caused by anthropogenic activities, some extreme events occur due 
to natural variability. Therefore, it is important to take natural variability into account for a better understanding of extreme events in the future alongside changes caused by anthrophonic activity (Field et al., 2012; United Kingdom Climate Change Risk Assesment [UKCCRA], 2017).

Climate change causes some alteration on weather events such as precipitation and temperature, and this is expected to be effective on a global scale. Additionally, in some regions, some extreme events have increased, they have become more frequent and more intense in particular regions (Herrero et al., 2018; IPCC, 2013). These observations have started to be seen with increasing concern. There is some evidence that many of these increases are related to human activities. (Ren et al., 2018).

Extreme events may cause serious problems for the environment such as floods, storms, and water contamination. To illustrate, when it rains much more than expected over a short time, floods can occur and cause serious and destructive harm to river flows, regimes and sediments depending on the size of the flood. Some positive changes in river water quality can be associated with the decrease in occurrence and duration of extreme events (United Kingdom Technology for Agriculture and Genetics [UKTAG], 2008)

The world has seen an increase of $0.85\left[0.65-1.06{ }^{\circ} \mathrm{C}\right.$ in the average global (combined land and ocean surface) temperature from 1880 to 2012. This trend in global warming has also been observed in England, which is reported in the central England temperature data series, which has good correlation with temperature data sets from other global sources (UK Climate Change Risk Assessment [UKCCRA], 2017). In recent decades, the UK has had milder winters and hotter summers, and since 1990, all ten of the warmest years in the UK have occurred during this period. Surprisingly eight of them have occurred since 2002 (Kendon et al., 2015). Furthermore, the frequency of heatwaves has started to increase and have occurred many times since 2000, with the most critical recorded heatwaves occurring in 2003, 2006 and 2018. These observations show that because of the impacts of climate change, extreme events, which have serious impacts on the environment, have started to be observed more frequently and intensively in recent years (Guillod et al., 2017). The UK Climate Change Risk Assessment Report (2017) concludes that extreme events such as floods, heatwaves, and droughts will become common threats for the UK and advises regulators to take serious and permanent precautions to mitigate these forecasts. 
If climate change mitigation plans are not adopted and extreme events such as floods and heatwaves become more frequent and intense in the future, such events could change the geomorphology of riverine habitat and the river ecology. It is possible to alter the river's quality and habitat quantity as extreme events such as floods change river geomorphology which consists of riparian, slope, discharge, catchment geology and sediment supply. Additionally, human activities such as engineering works for the protection of floods exacerbate the impacts of extreme floods on rivers by changing the riparian zones and river flows that minimize the river channel width over time (Death et al., 2015). During periods of extremes, a flood could not find enough channel width, and the destructive impacts of floods could be more intense (Death et al., 2015).

To deal with problems in water bodies, on October 2000, The European Parliament and The Council of The European Union published an establishment of a framework regarding water policy for their community actions (EU Water Framework Directive [WFD] 2000/60/EC, 2000). The aim of the WFD required all member states to achieve "good status" in all types of water bodies by establishing measurement programmes. For different types of water bodies, the Ecological Quality Status needs to be assessed by member states. For surface waters, the classification of ecological status is defined by Biological Quality Elements (BQEs), Physico-chemical Quality Elements (PCQEs) and Hydro-morphological Quality Elements (HMQEs) (Romero et al., 2013). Water bodies are classified into five categories used by the WFD classification scheme, and these are high status, good status, moderate status, poor status and bad status (Table 1). To achieve high status a water body must meet the conditions of each of the WFD Quality elements. A lower classification is based on the degree of deviation from reference conditions. The hydro-morphological quality element is only considered for water bodies that meet the other two quality elements. The WFD has set an objective for all water bodies in the EU to achieve at least 'good status' but almost half of the water bodies in Europe are currently below this standard. 


\section{Table 1}

Definition of Ecological Status of Water Bodies under the WFD (Environment Agency, 2006)

\begin{tabular}{|c|c|c|c|}
\hline \multirow{2}{*}{ Ecological Status } & \multicolumn{3}{|c|}{ Water Framework Directive Quality Elements } \\
\hline & $\mathrm{BQE}$ & PCQE & HMQE \\
\hline High status & Meets conditions & Meets conditions & $\begin{array}{c}\text { Meets } \\
\text { conditions }\end{array}$ \\
\hline Good status & $\begin{array}{l}\text { Deviates slightly from } \\
\text { reference conditions }\end{array}$ & Meets conditions & $\begin{array}{c}\text { Not } \\
\text { considered }\end{array}$ \\
\hline Moderate status & Moderate deviation & $\begin{array}{l}\text { Moderate } \\
\text { deviation }\end{array}$ & $\begin{array}{c}\text { Not } \\
\text { considered }\end{array}$ \\
\hline Poor status & Deviation & Major deviation & $\begin{array}{c}\text { Not } \\
\text { considered }\end{array}$ \\
\hline Bad status & Deviation & Greater deviation & $\begin{array}{c}\text { Not } \\
\text { considered }\end{array}$ \\
\hline
\end{tabular}

A hydro-morphology assessment considers the hydrological (water flow, energy) and geomorphological (surface features) attributes of water bodies and is a "supporting element" which means that for water bodies where ecological status is less than 'high status' or is changing status from high to good ecological status, the hydro-morphological state is not taken into account as a component of overall ecological status (Environment Agency, 2006). When used in the assessment of ecological status, both natural and anthropogenic variables including river flow regimes and fluvial geomorphology are considered. High status is determined if the water body has no or very minor anthropogenic changes regarding the HMQE (The Secretary of State, 2015). Additionally, as indicated previously, the WFD requires its members to define their rivers' ecological status based on BQEs, PCQEs, as well as HMQEs which consider the hydrological regime, river continuity, and morphological conditions as detailed in Annex V of the WFD (Ilnicki et al., 2010; The Secretary of State, 2015). It is known that any changes in ecological status could be the result of changes in one or more of the elements. Although chemical elements could be measured according to their main quality, hydro-morphological elements cannot be measured in the same way (Department for Environment, Food \& Rural Affairs [DEFRA], 2006).

HMQEs is one of the main parts of Ecological Quality Status for surface water bodies under the water framework directive (Reynard, 2010). By helping to describe conditions of water bodies, all EU members need to consider all mandatory 
and recommended parameters for these elements. Surface water bodies such as rivers, and lakes have specific HMQEs including the hydrological regime, river continuity and morphological conditions as reported in Annex V of the WFD, and these are described as 'supporting the biological elements' by the WFD (The Secretary of State, 2015; United Kingdom Technical Advisory Group [UKTAG], 2003). Assessment categories of surface water bodies defined by the WFD is shown in Figure 1.

It is known that any changes in ecological status could be the result of changes in one or more of each of these elements, and HMQEs are defined to be supportive of BQEs, and the reverse case could occur (Department for Environment, Food \& Rural Affairs [DEFRA], 2006; Environment Agency, 2006). It is not avoidable to have impacts on river biota whilst responding to the effects of extreme climate events and weaken ecological resilience. Any changes in river morphology, hydrology, and riparian cover could cause some problems for the cold water refugia such as salmonids. Also, any channelization for flood risk increases sediment loads and reduces habitat diversity (Whitehead et al., 2009). Furthermore, Feld et al.(2014) showed that one of the important pressures and major threats to lotic ecosystems and biodiversity in Europe is hydro-morphological alterations. Also, the study suggested that it is essential to develop and identify new indicators for detecting biodiversity loss and changes in ecosystems.

Moreover, increasing drought and flood intensity due to climate change can affect river flow regimes and morphology. Thermal impacts where reduced flow occur will be exacerbated by increased temperature. Moreover, having lower flows and higher water residence times in rivers can cause serious problems such as eutrophication, ecosystem functions, algal growth and decreasing oxygen level. It is also known that changes in water temperature can have impacts on aquatic systems and some species could be more sensitive to changes, even for small changes. Increasing rainfall comes with biophysical impacts such as diffuse pollution and soil erosion (Whitehead et al., 2009; UK Climate Change Risk Assessment [UKCCRA], 2012a; Orr et al., 2015; O’Briain, 2019). 


\section{Figure 1}

Assessment of Ecological Status of Rivers (Adapted from DEFRA, 2009; European Environment Agency [EEA], 2018)

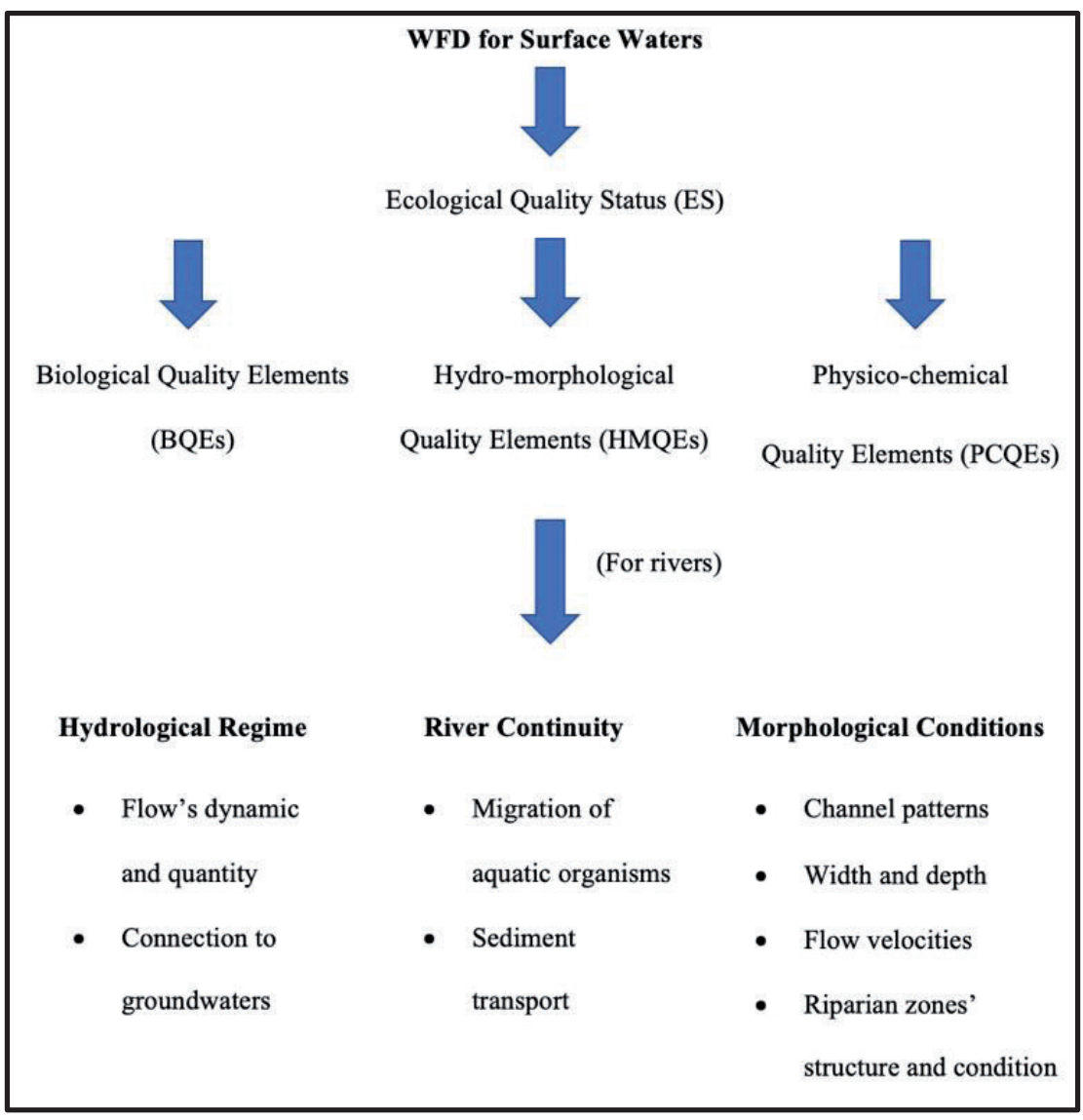

Any changes in air temperature and rainfall, projected by climate models could have impacts on river flows and alter dilution for pollutants. There is no doubt that chemical reaction kinetics, quality, and ecological status of water bodies will be affected by warmer water. Increased flows will cause some changes in stream power, sediment transfer and loads, which have the potential to change the morphology of rivers. Having lower flows in rivers could cause reduced dilution, and this could result in higher concentrations of pollutants, which makes the purpose of improving water quality standards hard within the WFD. Additionally, it will cause increased biochemical oxygen demand (BOD), lower dissolved oxygen (DO) concentrations, and have impacts on organic pollutant concentrations in rivers. While ammonia 
levels fall due to higher rates of nitrification, BOD and phosphorus levels increase under the reduced flows in the summer periods (Whitehead et al., 2009)

All monitoring programmes for assessment of river basins and flood risk should consider all ecological quality elements including hydro-morphological quality elements. Also, any effects of hydro-morphology on biological elements should be considered in the future within the timeframe of monitoring programmes. There are lots of differences among member state countries for giving priorities to hydro-morphological elements, and sediment transport is considered more in the River Basin Management Plans compared to Flood Risk Management Plans (Nones et al., 2017). To evaluate the rivers' hydrological and morphological conditions, direct and indirect pressures and nature of anthropogenic changes must be considered by the appropriate agency (The Secretary of State, 2015).

It was expected that all EU members would reach good status in all water bodies by 2015, called the first planning cycle; however, many member states faced problems to develop programmes and had limited change in their ecological status. Nearly half of the surface water bodies within the EU remained the same and did not reach the aims of the WFD. Additionally, in the first cycle (from 2009 to 2015), only $10 \%$ of water bodies that were classified at a moderate status or below reached good status. Therefore, the timeline to achieve good status was postponed to 2027 (Giakoumis and Voulvoulis, 2019; Van Rijswick and Backes, 2015).

Any changes in the future climate or socio-economy may affect the ability of member states to reach desired environmental conditions to achieve the required WFD ecological status. To exemplify, it is known that the objectives of the WFD could be more difficult by the worsening hydro-morphological issues and nutrient enrichment in the 2050s across Europe, which also applies for England and Wales. It is expected that hydro-morphology will be degraded in the future, and there should be more measures for dealing with these challenges with sustainable and costeffective approaches and adaptations for common issues in different scenarios (Henriques et al., 2015)

An assessment of the ecological status of the UK in 2009 reported that almost half of the surface water did not meet good status. It was determined that there were many significant pressures from the point and nonpoint sources, hydromorphological alterations and other pressures which impacted on water bodies in failing river basin districts. Additionally, UK forecasts mention the increase of precipitations and temperatures and extreme events, which will continue to increase and be more frequent in the future, however; there is not enough knowledge 
regarding re-occurrence time. Serious and permanent precautions for the protection of bodies is required to mitigate these threats (UK Climate Change Risk Assessment [UKCCRA], 2012). Modelling studies of UK climate predicts hotter summers which are expected to cause lower river flows and reduce water levels. Extreme events such as heatwaves also place pressures on the demands of water supply.

This study reports on the pressures and negative impacts of extreme weather events on hydro-morphological quality elements of water bodies in the United Kingdom. The paper considers the UK's weather changes and trends over the last century and identifies and considers the possible obstacles and barriers resulting from climate change and extreme events in the implication of the WFD in the UK in the future.

\section{Method}

\section{Design and Search Strategy}

The Web of Science and Scopus databases were used to address the objectives of the research. Searches were limited to English articles, published between January 1980 to present in peer-reviewed journals. UK Met Office meteorological data sets were searched for parameters such as temperature, rainfall and extreme event occurrence in the UK. Climate and other factors that could impact on HMQEs related to river hydro-morphology were determined using data sets available online. Additional parameters that have the potential to impact or change hydro-morphological quality elements were identified to assess potential problems for the implementation of the WFD in the UK. The following parameters were considered:

Temperature: To visualize the changes over the world from 1850 to 2018 and in the UK from 1884 to 2018, data sets were obtained from the UK Met Office. Additionally, maps showing temperature changes over the world and the UK was obtained from IPCC. Data for extreme events including drought periods were obtained from the UK Met Office. For future assessment, United Kingdom Climate Projections 18 data was used ( UK Climate Projections 18 [UKCP18], 2018)

Rainfall: To assess observed rainfall trends in the UK, data containing annual, seasonal, and monthly participations values (mm) from 1910 to 2018 collected from the UK Met Office was used. For future assessment of precipitation changes, data was obtained from UKCP18 for the UK under five different scenarios, and from IPCC for world rainfall records. 
River changes: To show any changes in rivers, data such as river flows was obtained from the UK National River Flow Archive, the UK Monthly Hydrological Summaries, Environment Agency River Hydrology, Annual State of the UK Climate, and Centre for Ecology \& Hydrology.

\section{Data Analyses}

To analyse data sets to learn any impacts of extreme events on rivers, firstly data sets were reproduced using Microsoft Excel. Periodical and overall min, max, and mean values were compared and shown in the graphs to see how rainfall and temperature trends changed over the years. Also, regional values were compared to see how the UK was affected by extremes regionally. Weather maps from the UK Met Office were used and compared to assess how extreme weather events were effective over the UK. The differences and connections between hydromorphological variables such as river flows, channel width, and riparian zones and extreme weather conditions such as heatwaves, floods, and droughts were identified by comparing the periodical weather results. For future assessment, different scenarios were shown in the same graphs, which allowed comparing the projections related to weather patterns.

\section{Results and Discussion}

\section{Climate Change and Extreme Events Analyses}

Many physical responses such as changes in air temperature, in rainfall, the melting of glaciers and ice sheets, and increasing sea levels are indicators of climate change (IPCC, 2013). According to IPCC, even if global warming was limited at 1.5 degrees above pre-industrial levels, the effects of climate change would still be effective on earth. Such scenarios demand planning and preparedness for adverse weather effects including storms, sea-level rise, heatwaves, weather-related diseases, and other effects that have adverse impacts on society and the environment (Emma, 2018).

Although regional climate change outcomes are uncertain, many latest assessments include the projection of changes in the occurrence of weather and climate events, which mainly focuses on frequency, intensity and duration. These changes, with increasing vulnerability, could increase stress on society and environment, and increase the tendency for adverse effects of climate change around the world (Field et al., 2012). 
Since the 1950s, extreme events and climate events, such as a decrease in cold temperature extremes and the increase in warm temperature extremes and heavy rainfall events have started to change, some of these changes have been linked to anthropogenic influences. Other changes in extremes, that could occur include an increase in the number of warm days and nights, and a decrease in the number of cold days and nights globally. Also, in most of Europe, Asia and Australia, there has been an increase in the frequency of heatwaves and the intensity and occurrence of the temperature extremes. ((Intergovernmental Panel on Climte Change [IPCC], 2014).

\section{UK temperature analysis.}

The dominant cause of global and UK temperature changes can be attributed to increasing greenhouse gases (GHGs) in the atmosphere. Furthermore, there is a substantial body of evidence that suggests that these emissions are due to human activities rather than natural causes and the observed temperature changes are not a result of natural climate variations (Adger and Brown, 1993). These findings are based on national inventories of greenhouse gas emissions, which form a part of the UK's ratification the United Nations Framework Convention on Climate Change (UNFCCC) which came into force in March 1994. Under its obligation to the convention, the UK is required to regularly update national emission inventories of GHGs. A report lasts submitted in 2019 (Brown et al., 2019) contains national greenhouse gas emission estimates for the period 1990-2017 and includes descriptions of the methods used to produce the estimates.

Evidence of global warming is highly convincing, global temperature measurements from worldwide records show that average temperatures have risen by nearly $0.8^{\circ} \mathrm{C}$ since the late $19^{\text {th }}$ century, which is a rise of $0.2^{\circ} \mathrm{C} / \mathrm{decade}$. This is also the case of temperature records in the UK, which like other parts of the world also show significant trends towards higher temperatures; i.e. in England, temperatures have risen by $1{ }^{\circ} \mathrm{C}$ since the 1970s. Temperatures have also increased in other parts of the UK, in Scotland and Northern Ireland they have arisen by $0.8^{\circ} \mathrm{C}$ since 1980 (Jenkins et al., 2008). Recent decades have seen the largest increase in temperature, for example, the last decade in England was the second hottest in the past 100 years and eight new high-temperature records have been set during the last two decades. When compared to the annual average UK land temperature during the period of 1961-1990, the period of $2005-2014$ was $0.9^{\circ} \mathrm{C}$ higher, and 2014 was the warmest year. While ten of the warmest years has observed since 1990, and eight of them has occurred since 2002 (Karoly and Stott, 2006; Kendon et al., 2016). 
Hawkins (2019) visualised these temperature trends using an animated spiral graphic and later he used warning strip charts, that contain chronologically ordered coloured stripes to describe the temperatures in the UK for the period $1850-2018$. The warning charts show that most warming years were observed in the last two decades and the latter part of the last century. Alongside higher mean temperatures over lands and seas, the UK has also experienced more extreme events and experienced milder winters and hotter summer in recent years (UK Climate Change Risk Assessment [UKCCRA], 2017).

Global climate models (GCMs) have been used to predict how temperatures will change around the world. To analyse specific regions, regional climate models (RCMs) have been useful tools in providing fine-scale and regional results. One of the RCMs is the United Kingdom Climate Projections (UKCP), first published in 2009, and supported by the UK Met Office and DEFRA (UKCP18), were used with finer scale and more detailed information by covering both land and surrounding seas around the UK. These models show that UK annual average temperatures will change by 2100 under five different scenarios at the 95 th percentiles. Scenarios are for the low (RCP2.6), medium (RCP4.5 and RCP6.0), high emissions (RCP8.5), and the UKCP09 medium emissions scenario (SRES A1B), relative to baseline of 19812000. Even if the low scenario (RCP2.6) remained effective, the UK would still be warmer and there would be around $0.75{ }^{\circ} \mathrm{C}$ increase in annual average temperature, while the scenario would progressively get worse and for the high emissions (RCP8.5) the temperatures will increase around $8.6{ }^{\circ} \mathrm{C}$ (Lowe et al., 2019).

\section{UK rainfall analyses.}

Over the past 100 years, while the global precipitations have changed, the UK climate has also changed with an increase in the winter rainfall and a decrease in the summer rainfall. While more heavy rainfall events are observed winter rainfalls, the summer rainfall decreases (Emma, 2018).

In Figure 2, it is shown how the precipitations changed in the UK from the 1910s to 2018 with the value of min, max and average of 1981-2010, 1910-2018, and 1910-1980 period. While the wettest period was observed in 2000 and 2012 with $118 \%$ of average, the driest period was observed in 1993 with $74 \%$ of average. Since 1998, seven of the ten wettest years has observed. These are 2000, 2012, 2014, 2008, 2002, 2015, and 1998, respectively. 


\section{Figure 2}

The UK Rainfall Time Series from 1910-2010 (Data from UK Meteorological Office, 2019)

UK Rainfall 1910-2010

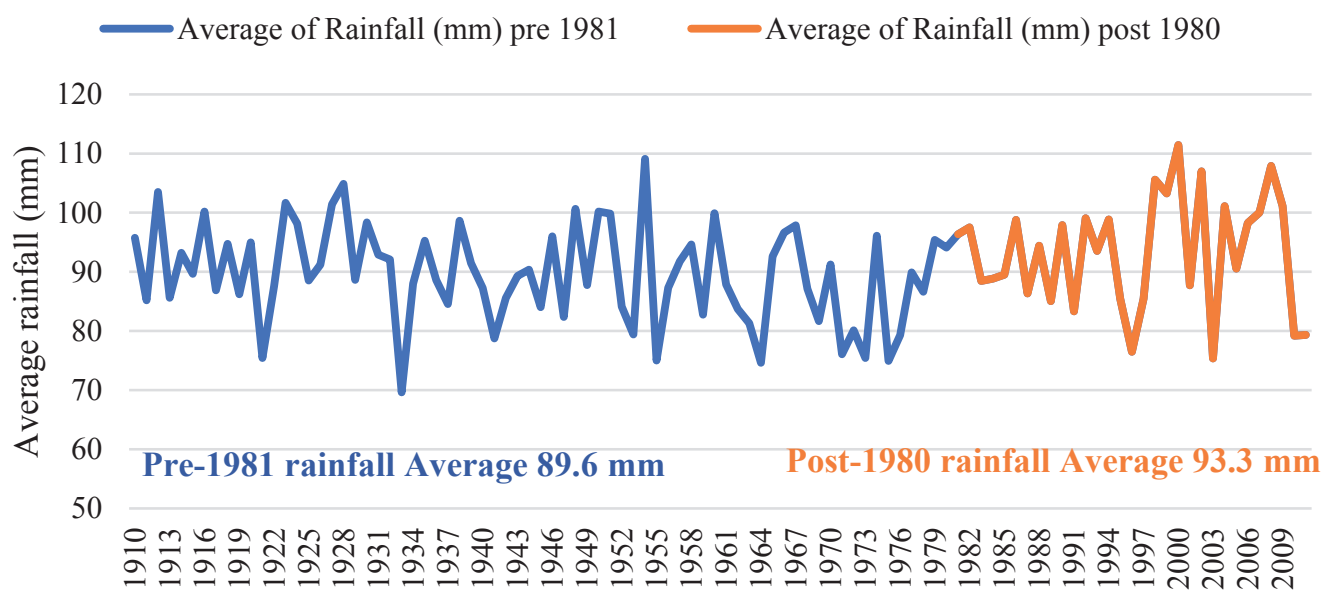

Under the five different scenarios, UKCP18 has projected the changes in the precipitation over areas of the UK. Although annual average rainfall may not change over the $21^{\text {st }}$ century, it is expected to increase in more extreme events (Emma, 2018). In the UKCP18, it is found that while a smaller increase is observed over Scotland, a larger increase is observed in the South of England. In projections of changes in 30-year mean annual, winter and summer mean precipitation by the $2050 \mathrm{~s}$ under the medium emissions scenario, the UK is expected to see increases in winter rainfall by approximately $5 \%$ to $30 \%$, and to see $20 \%-40 \%$ decrease or $1 \%-7 \%$ increase in summer rainfall (UK Climate Change Risk Assessment [UKCCRA], 2012). Projections show that while warmer and wetter climate will occur in winters, hotter and drier climate will occur in the summer. As a result of natural variability in the climate system, natural structure of the winter and summertime periods, cold and drier winters, or wetter summer will still occur with less frequency.

\section{UK Extreme Events}

\section{Heatwaves.}

The UK has undergone many heatwaves since the beginning of the $20^{\text {th }}$ century. Figure 3 shows the summer mean temperature from 1910 to 2018 in the UK. The warmest summer of 1911 was equal with 1976, 2003, 2006 and 2018. 


\section{Figure 3}

Summer Mean Temperature in the UK from 1910 (Data from UK Meteorological Office, 2018a)

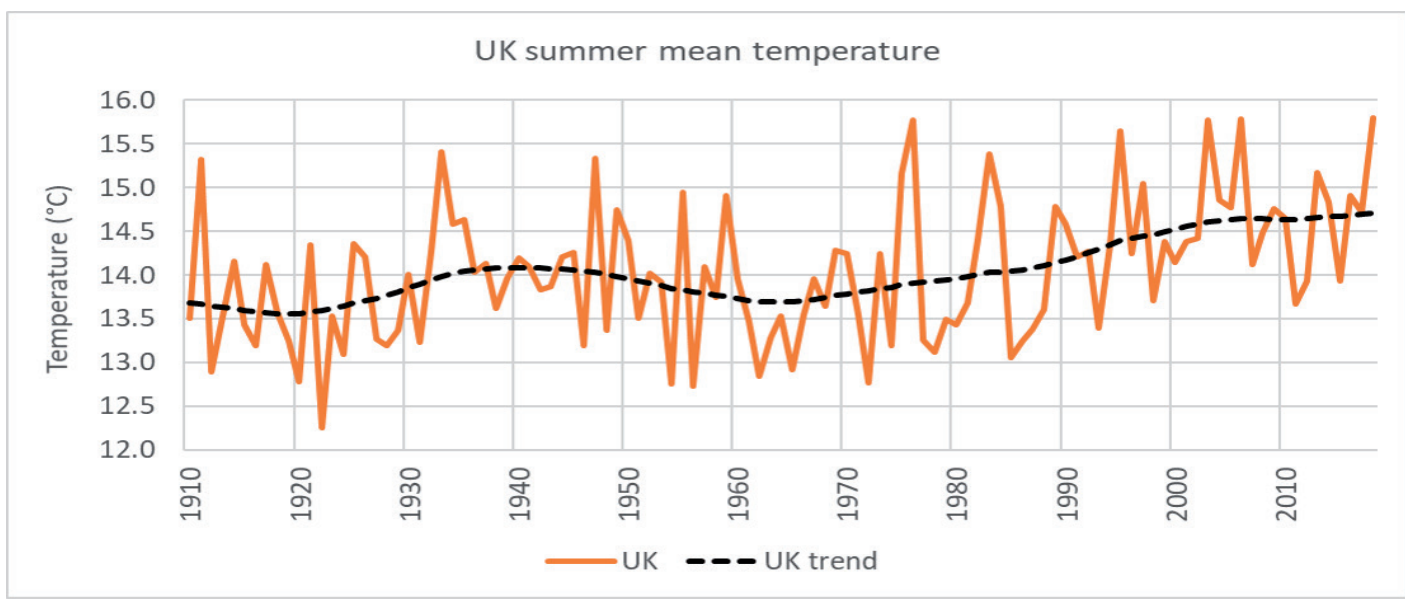

Since the 1980s, heatwaves have started to become more frequent and the trend from 1910 to 2018 is upward, which has seen average summer temperatures increase by about $1.0^{\circ} \mathrm{C}$ from an average daily temperature of $13.6^{\circ} \mathrm{C}$ to $14.6^{\circ} \mathrm{C}$. Furthermore, the average maximum temperature is also increasing. Table 2 shows that during the period 1981-2010 compared to the period 1961-1990, the maximum average temperature has increased in every month between the two time periods (annual average increase between the two periods is $0.6^{\circ} \mathrm{C}$ )

\section{Floods and heavy rainfalls.}

Many extreme events including floods and heavy rainfalls have been intensively and frequently observed in the UK since the late $20^{\text {th }}$ century. There has been a 17\% increase in the total amount of extreme rains from 2008 to 2017, when compared to the 1961-1990 period. Figure 4 shows how the UK's rainfall changes annually, showing an incremental trend upwards over the last 30 years period. Additionally, while the largest changes are observed in Scotland, most of the southern and eastern areas are not affected as much. Although the extreme events vary inter-annually, the general trend is consistent with the increase in the rainfall over the UK. 


\section{Table 2}

UK Average Temperatures (Maximum and Minimum Average Temperatures in the Periods 1981-2010 and 1961-1990, and the Difference in Maximum Average Temperature)

\begin{tabular}{c|c|c|c|c|c}
\hline \multirow{2}{*}{ Month } & \multicolumn{2}{|c|}{ Climate Period $1981-2010$} & \multicolumn{2}{c|}{ Climate Period 1961-1990 } & \multirow{2}{*}{$\begin{array}{c}\text { Difference in } \\
\text { Maximum }\end{array}$} \\
\cline { 2 - 4 } & $\begin{array}{c}\text { Maximum } \\
\text { Temperature }\left({ }^{\circ} \mathrm{C}\right)\end{array}$ & $\begin{array}{c}\text { Minimum } \\
\text { Temperature } \\
\left({ }^{\circ} \mathrm{C}\right)\end{array}$ & $\begin{array}{c}\text { Maximum } \\
\text { Temperature } \\
\left({ }^{\circ} \mathrm{C}\right)\end{array}$ & $\begin{array}{c}\text { Minimum } \\
\text { Temperature }\left({ }^{\circ} \mathrm{C}\right)\end{array}$ & $\begin{array}{c}\text { Temperature } \\
\left({ }^{\circ} \mathrm{C}\right)\end{array}$ \\
\hline January & 6.4 & 0.9 & 5.7 & 0.4 & 0.7 \\
February & 6.6 & 0.7 & 5.8 & 0.2 & 0.8 \\
March & 8.9 & 2.1 & 8 & 1.4 & 0.9 \\
April & 11.4 & 3.4 & 10.6 & 2.8 & 0.8 \\
May & 14.7 & 6 & 14.1 & 5.5 & 0.3 \\
June & 17.3 & 8.8 & 17 & 8.4 & 0.8 \\
July & 19.4 & 10.9 & 18.6 & 10.2 & 0.7 \\
August & 19.1 & 10.8 & 18.4 & 10.2 & 0.5 \\
September & 16.5 & 8.8 & 16 & 8.4 & 0.1 \\
October & 12.8 & 6.2 & 12.7 & 6.2 & 0.7 \\
November & 9.1 & 3.3 & 8.4 & 2.7 & 0.2 \\
December & 6.7 & 1.1 & 6.5 & 1.2 & 0.6 \\
Annual & 12.4 & 5.3 & 11.8 & 4.8 & \\
\hline
\end{tabular}

\section{Figure 4}

Annual Rainfall Changes in the UK from 1910 to 2018 (Data from UK Meteorological Office, 2019)

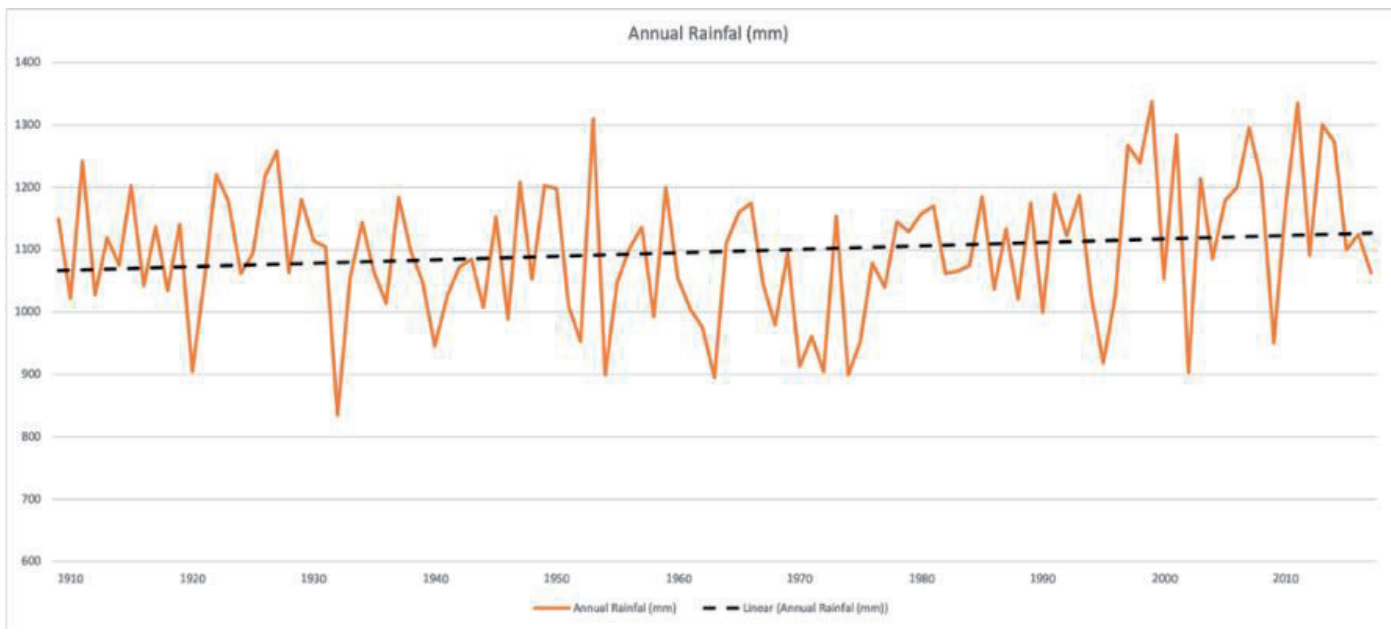


The period 2008 to 2017 has set several new rainfall records. The months of May, June and July in 2007 were exceptionally wet months with twice the 19611990 average. And 2012 was one of the wettest years in the UK with several destructive floods. During the year, most parts of England, Wales and eastern Scotland received twice or three times the average rainfall. Also, some local areas received over four time average (UK Meteorological Office, 2012). In December 2013 and January 2014, the UK experienced some of the most widespread and destructive floods on record which occurred in many parts of the UK. In Scotland, the rail network had periods of shut down, and many houses were left without power for weeks. While in December, heavy rainfall was effective over Scotland, the south part of the UK was affected severely in January (Figure 5) (UK Meteorological Office, 2014).

\section{Figure 5}

December 2013 and January 2014 Rainfall with 1961-1990 Average UK Meteorological Office, 2018b)
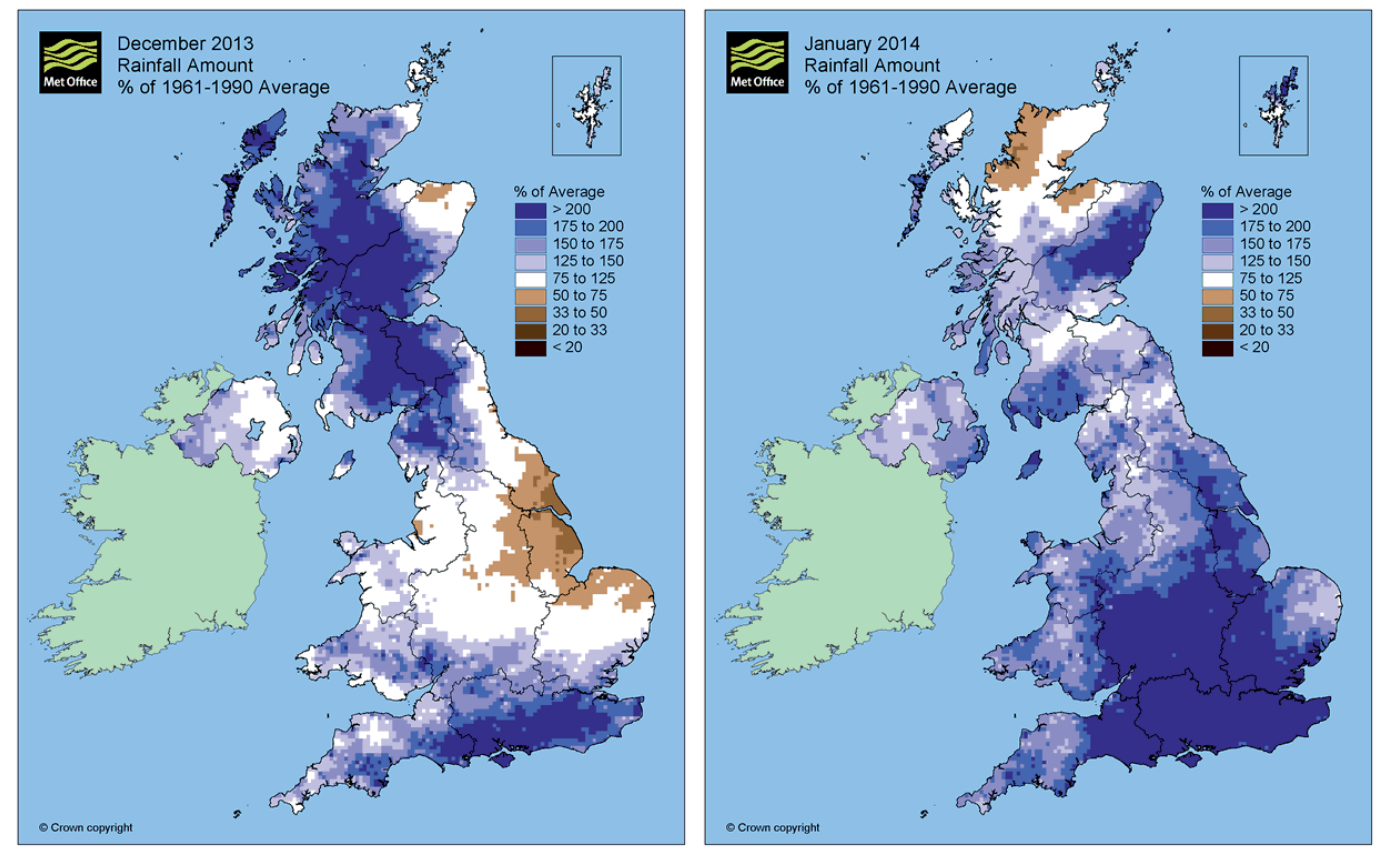

The IPCC $5^{\text {th }}$ Assessment Report for policymakers' forecasts that the UK will see a rise in rainfall of about $10 \%$ in annual average rainfall by 2100 compared to the period 1985-2005. The forecast also predicts that the UK is very likely to see more heavy rainfall events in the next 50-100 years. Heavy and prolonged rainfall 
events, resulting in lots of rain falling in a short time will lead to a higher incidence of flooding over time. The economic growth of the United Kingdom, particularly certain parts of the UK such as the South East of England have seen a significant increase in property developments on floodplains over the past 10 years and one in five of those properties is at risk of flooding. In the UK, between 2001 and 2011, 200,000 homes were built in floodplains. Therefore, the increase in heavy rainfalls places these developments at high risk.

\section{Impacts of Climate change and Extreme Events on Hydro-morphological Quality Elements}

The UK's surface, transitional and coastal waters are highly affected by anthropogenic activity. Like many other countries, the UK has over the centuries changed the course and character of its water bodies to make water available for agriculture, to develop urban areas, to produce hydroelectric power or to protect its communities from flooding. Physical changes to water bodies that result from activity such as water abstraction, water flow engineering (dams, weirs, and locks), morphological alterations (changes to the channel, riparian and flood plain) are called hydro-morphological pressures as they alter the water flow dynamics and morphology (or physical structure) of the water body. Hydro-morphological changes can induce habitat alterations i.e. change in flow frequency, flow duration, change in sediment transport, loss of floodplains or intertidal area, change in river profile and estuaries and change in connection with groundwater (Kristensen et al., 2012). Therefore, Hydro-morphological pressures can have a significant impact on the aquatic environment.

In addition to direct impacts of anthropogenic alterations, the hydromorphology of a river can also be affected by climate change. One of the significant results of climate change may be the increase, duration and intensity of extreme events such as floods or heatwaves, which affect the hydrological conditions of rivers, including flow and water levels (Bauwens et al., 2013; Hannaford, 2015; Lehner et al., 2006; Nováky and Bálint, 2013). These events are also known as hydrological hazards which are associated with water's movement, distribution and occurrence. Because of the complexity of systems and the interaction between hydrology and climate, for any given system, the changes it experiences in hydrological and morphological conditions is generally not widely understood or extensively studied (Arnell, 2003; Guan et al., 2016; Visser-Quinn et al., 2019; Yousefi et al., 2018). 
River flow regimes are key indicators of anthropogenic climate-driven changes in river flows (Hannaford, 2015). River flow regimes help understand how spatial and temporal changes occur and to identify any future changes. Additionally, it is possible to identify and learn the river or catchments sensitivity to climate change (Bower et al., 2004; Howden et al., 2009). This type of studies to understand the relationship between climate change and extreme events and river flow is helped by the excellent gauging station network, consisting of 1400 stations. The data from these stations is kept by the National River Flow Archive. However, most of the gauging stations were installed in the 1960s and 1970s and therefore there is a lack of data from the $19^{\text {th }}$ or early $20^{\text {th }}$ century. Furthermore, there is considerable missing data from stations particularly during extreme flow periods of very high or low flow episodes (Dixon et al., 2006).

\section{River flow changes in the UK during heatwaves.}

Although low river flows as a consequence of dry weather which occur during heatwaves receive less attention than high flows caused by high rainfall, low flows are nevertheless a significant issue. Reduced flows reduce the protective dilution effect of rivers on aquatic life, leading to changes and the loss of habitat for aquatic animals and plants. For example, fish deaths increase during droughts and low river flow. Also, during low flow events, water abstraction for agriculture and water supply needs to be constrained, affecting households, agriculture and industry.

Evidence of low river flows during drought periods in the UK is available during two record-breaking heatwaves during this century. Figure 6 shows river flows in the July heatwave of 2006. The river flow changes were collected from monthly hydrological and described as; exceptionally high flow (black), notably high flow (dark blue), above normal (blue), normal range (green), below normal (yellow), notably low flow(orange), exceptionally low flow (red).

River flow changes in the UK during the 2018 heat wave provide further evidence of climatic effects, shown in Figure 7. The figure illustrates that river flows were highly affected during heat waves, showing that flows in May were normal, occasionally below average, but almost $80 \%$ of river flows were under normal range and some exceptionally low in July (the peak of the heatwave). In August 2018, the status was getting better and turned into normal in September. 


\section{Figure 6}

River Flow Changes in the UK During the July 2006 Heatwave (Adopted from The Natural Environment Research Council's (NERC) Centre for Ecology \& Hydrology (CEH) [NERC CEH], 2018)
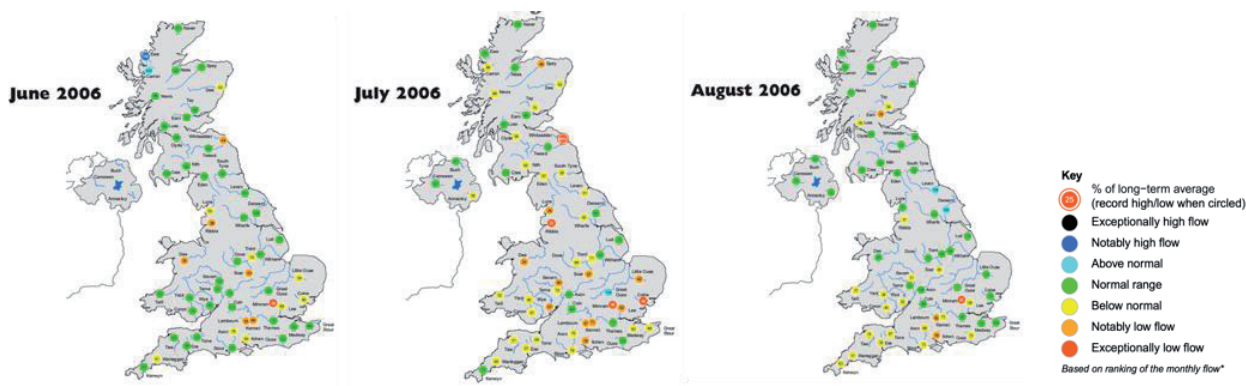

\section{Figure 7}

River Flow Changes in the UK During the 2018 Summer Heatwave (Adopted from The Natural Environment Research Council's (NERC) Centre for Ecology \& Hydrology (CEH) [NERC CEH], 2018)
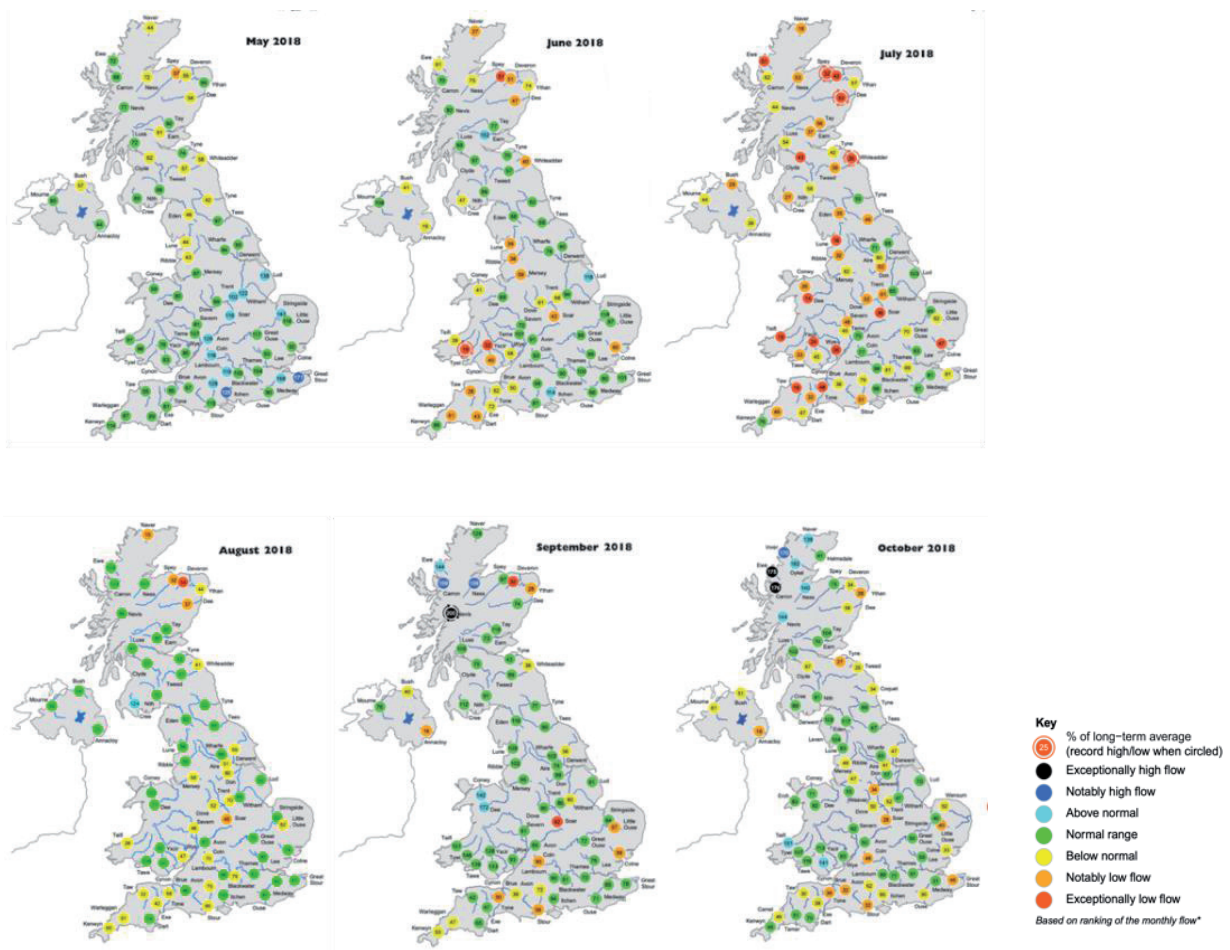


\section{River flow changes in the UK during heavy rainfalls.}

In addition to impacts of heatwaves on river flows, heavy rainfalls also have significant impacts on river flows including flooding. The UK experienced heavy and prolonged rainfall and flooding during 2007, 2012, and 2013-2014, the flooding had very destructive effects on a large number of communities in the UK. During these periods, many parts of England, Northern Ireland, and Scotland were under heavy rainfall which caused these areas to be extremely wet. When analysing the river flow changes during this period, it is found that rivers were above average flow, some had exceptionally or notably high flow as shown in Figure 8. The UK, especially central England were most affected by these extreme events in 2007.

\section{Figure 8}

River Flow Changes over the UK in 2007, 2012, and 2013-2014 (Periods of Heavy Rainfall) (Adopted from The Natural Environment Research Council's (NERC) Centre for Ecology \& Hydrology (CEH) [NERC CEH], 2018)
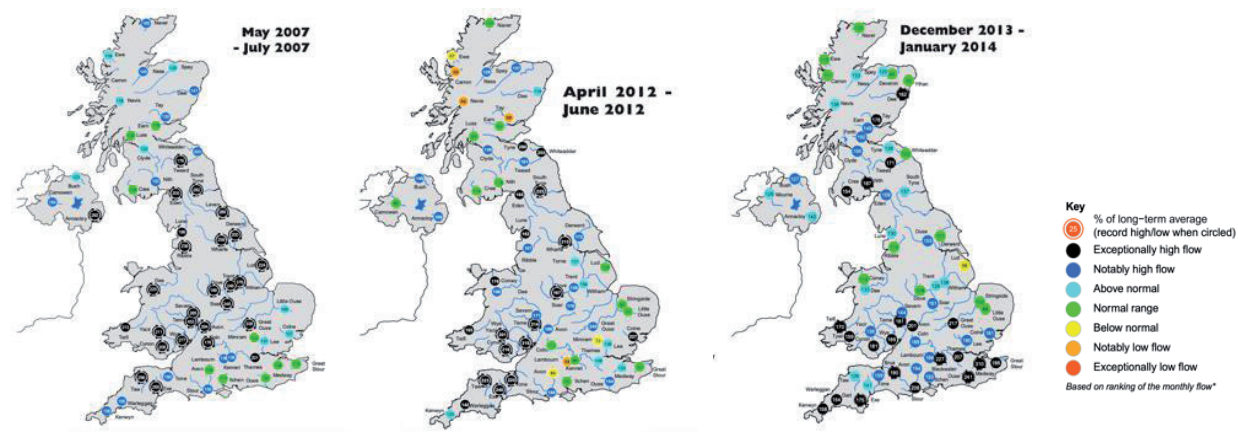

Therefore, it is possible to say that the river flows are affected by extreme events. These effects could be either more flows above average that can cause floods and heavy rainfalls, or fewer flows below average for heatwaves.

Although many studies have focused on the relationship between hydrology and geomorphology, only a few studies have been conducted for analysing the effects of extreme events on channel hydrology and morphology (Yousefi et al., 2018). According to Phillips (2002), it is found that flash flooding has impacts on geomorphology and has caused channel changes.

The study for seasonal analyses in the UK was conducted by Hannaford and Buys (2012). It is observed that while north and west part of the UK's winter high flows were at a high level, central and southwest England and eastern Scotland's 
autumn high flows were at a high level. Also is found that there was an increase in the high flows of some lowland catchments and that although summer and spring flows were more complex and mixed, in some regions there were increase trends in both seasons. Other studies also showed that results are generally on the same side for the UK and that there is a tendency to increase high flows. (Hannaford, 2015).

Moreover, according to Dixon et al. (2006), flow regimes at 56 gauging stations from 1962 to 2001 in Wales And English Midlands were analysed. It is found that while significant high flow trends were observed in winter in the west of studies, flows were at a high level in east of study areas in autumn. Additionally, from 1977 to 2016 period, the increase in the annual and autumn extreme flows was observed in the Severn uplands (Biggs and Atkinson, 2011).

On the contrary, according to Hannaford (2015), there is no sufficient evidence for any long term trend (decrease or low flows) in river flows. However, past events showed that there has been remarkable hydrological volatility and that the UK rivers have been vulnerable to extremes such as major floods and storms in winters.

As indicated above, the frequency of extreme events is increasing. More heavy rainfalls accelerate the soil erosion and cause the contamination of watercourses and loss of valuable soils. Floods are the main cause of erosion, waterlogging and compaction. (Environment Agency, 2018; Reynard, 2010)

Additionally, changes in the width of River Dane, Bollin, and Severn in various years are shown in Table 3 . In the study conducted in these rivers showed that there was a seasonal difference in the high flow events, and the complexity in the morphology and flows was observed. Other factors such as extended growing season and vegetation may have significant impacts on them (Hooke, 2006).

\section{Table 3}

Changes in Width of Channels

\begin{tabular}{|c|c|c|c|}
\hline River Dane & 1984 & 1996 & 2001 \\
\hline Width (m) & 18.6 & 15.7 & 17.2 \\
\hline Last peak Q $\left(\mathrm{m}^{3} \mathrm{~s}^{-1}\right)$ & 79.4 & 20 & 130.7 \\
\hline River Bollin & 1970 & 1984 & 2001 \\
\hline Width (m) & 10.3 & 8.0 & 9.85 \\
\hline Last peak Q $\left(\mathrm{m}^{3} \mathrm{~s}^{-1}\right)$ & 39.56 & 38.91 & 48.65 \\
\hline River Severn & 1973 & 1984 & 1992 \\
\hline $\begin{array}{c}\text { Width }(\mathrm{m}) \\
\text { Last peak Q }\left(\mathrm{m}^{3} \mathrm{~s}^{-1}\right)\end{array}$ & $\begin{array}{c}21 \\
131.18 \\
\end{array}$ & $\begin{array}{c}25.5 \\
207.11\end{array}$ & $\begin{array}{c}26.5 \\
230.97 \\
\end{array}$ \\
\hline
\end{tabular}


Apart from the studies in the UK, a study conducted in Iran confirmed the impacts of extremes on rivers and found that flood discharge on 14 April 2016 was at the highest level in records for the last 60 years in Karoon River. Also, it is found that the channel width was significantly affected by extreme floods by analysing the OLI Landsat images taking before and after the flood. An increase from $192 \mathrm{~m}$ to $256 \mathrm{~m}$ in the average channel width was observed. Moreover, extensive bank erosion (almost 1290ha) because of increased flow power caused the channel width (Yousefi et al., 2018). Additionally, the result of this study goes hand in hand with the study conducted in Austria. In this study, it is found that extreme flood had impacts on rivers and widened the channel (Hauer and Habersack, 2009).

Moreover, it is known that one of the results from a series of floods is the sediment exhaustion and that more effective floods may have more impacts on sediment changes from earlier floods. Therefore, it is more complex to understand the series of floods' effects on sediment dynamics and channels than single floods (Carling, 2013). During most high flow events, sediments tend to move, and movement can be vary depending on sediment size and hydrological regime of river (Hooke, 2006). In the UK, it is expected that extreme events will occur more frequently and with greater intensively as described above. According to Boardman (2015) and Burt et al. (2015), the increasing trend in average rainfall could cause an increase in soil erosion in southern England.

Additionally, the impacts of extremes on the river channel has been reported by Guan et al. (2016), and it is found that extreme floods have an essential impact on adjusting the river channel. The channel changes due to extreme events have impacts on flood hazards and will be increased with more extreme flooding. Therefore, it can be described as a chain or cycle that affects each other. While extremes affect the channel conditions, any changes in the channel conditions can cause greater impacts of extremes, as it is more vulnerable to any changes and external factors.

While, in higher flood events, more erosion is observed, more deposition is observed in lower events. Therefore, it is possible to say that sequential high flow year may cause an increase in the channel width and that lower and single peak flows may result in more deposition (Hooke, 2006). On the contrary, to improve morphology, increase sediment porosity, and enhance the instream and riparian fauna and flora, some low and artificial floods have been used, which removed the lateral sediments and restricted the riverbeds (Mürle et al., 2003). 
Many studies have shown that having riparian vegetation has been an effective and cheap way to protect and minimize the effects of floods on banks, and that most riparian vegetation areas are less eroded. It is also responsible for the many natural systems related to water quality. However, as riparian vegetation seems to be an interface between water and territory, in extreme events such as flash floods, it is not possible to deal with floods' destructive impacts (Fernandes et al., 2016; Keesstra et al., 2012; Yousefi et al., 2018).

A study conducted by Fernandes et al. (2016) showed that the most important factor that caused changes in riparian is hydrological changes under the extreme water scarcity. It is found that an expected decrease in the annual mean flows in rivers will cause riparian shrinkage in the 21 st century. These results were also corroborated by the other studies conducted by Poff and Zimmerman (2010) and Rivaes et al. (2014). The low natural streamflow caused by extreme events also leads to a reduction in both patch size and riparian zone areas. Without any adaptation, it will be more vulnerable to climate change, and will alter the overall ecosystem functions as it is an important part of them (Capon et al., 2013).

It is also reported by Garssen et al. (2014) and later by Carolina (2015) that intense and long term drought more than 30 days has impacts on narrowing the riparian wetland zone, with accelerating the riparian wetland species losses. On the other hand, modelling studies showing how the flow regime changes due to climate change confirmed that riparian areas are expected to decrease in the areas most affected by climate change (Rivaes et al., 2013).

In addition to direct impacts of extremes on riparian zones, wildfire danger should be taken into account, as high temperatures and strong winds enhance the occurrence of fire.

To simplify and summarize, Table 4 shows the effects of extreme events on river hydro-morphology on changes and risks on HMEQs. 


\section{Table 4}

Important Risks and Changes from Extreme Weather Events on River Hydromorphology

\begin{tabular}{cc}
\hline Extreme Events & Risks and Changes on HMQEs \\
\hline Heatwave & Low River Flows \\
& Low Water Levels \\
& Riparian Shrinkage \\
& High River Flows \\
& Riparian Changes due to Soil Erosion \\
Mlood & Mitigation of Aquatic Organisms \\
& Sediment Exhaustion \\
& Channel Changes due to More Deposition \\
& Increased Channel Width \\
\hline
\end{tabular}

\section{Impacts of Human Induced Modifications on River Hydro-morphology}

Water retention, abstraction, hydropower, metering, tourism, recreation, and any other activities related to anthropogenic progress have impacts and pressures on water ecosystems, especially rivers. The rivers' physiochemistry, hydro-morphology and hydrology can be modified by intense human activities to deal with the effects of climate change. The most common pressures (Table 5) for hydro-morphological alterations are non-natural flows, damming, straightened planforms, reinforced banks and in-channel structures in the rivers, has caused many rivers in Europe and the UK to be below good ecological status. (Bauwens et al., 2013; Colas et al., 2017; Nováky and Bálint, 2013; Rinaldi et al., 2013; Shuker et al., 2015; Villeneuve et al., 2018)

In urban areas, the term Urban River Syndrome described by Walsh et al. (2005) explains the ecological degradation of streams draining to urban land due to alteration of low regimes. Symptoms of urban stream syndrome include changes in channel morphology, increase of pollutants and nutrient, reduced biotic diversity and increase in tolerant species (Elbrecht et al., 2016; Shuker et al., 2015). Flows and riverine ecosystems are affected by regional developments and land use for water withdrawals. Increased point and nonpoint source pollution from urban and rural areas is a problem for the alteration of hydro-morphology. It is also possible to say 
that dry or wet deposition of pollutants has impacts on alterations (Johnston et al., 2017).

It is identified that almost $75 \%$ of the UK rivers have regimes that cannot be considered as natural due to hydrological alterations (Black et al., 2005). The UK Environment Agency published in 2011 a report on the state of river habitats in England and Wales in which they report that river channels have been extensively modified across England, Wales and the Isle of Man. The report states that over many centuries, rivers have been straightened, widened, deepened and dammed, mainly to improve farming or to reduce the risk of flooding. As a result, river habitats have become impoverished and the biodiversity of wildlife they support has declined. These impacts on ecological health are worsening in some areas as the demand for water increases, directly affecting river systems by excessive withdrawing of water (Environment Agency, 2018). These effects are particularly problematic during drought conditions when there are reduced flows. In the UK many rivers are affected and influenced water abstractions and discharges (Wade et al., 2015). These effects pose problems for meeting WFD good ecological status in rivers.

\section{Table 5}

Potential Drivers for Causing Pressures on Surface Water Morphology

\begin{tabular}{|c|c|}
\hline Potential Driver & Examples of Specific Pressure \\
\hline Agriculture & Water abstraction, river straightening, grazing \\
\hline Urban development & Building weirs, dams, building flood banks \\
\hline $\begin{array}{c}\text { Water supply and } \\
\text { wastewater management }\end{array}$ & Water abstraction/discharge \\
\hline Power generation & Changes to flows \\
\hline $\begin{array}{l}\text { Mining, quarrying and } \\
\text { mineral extraction }\end{array}$ & Water abstraction/contamination \\
\hline Hydraulic fracturing & Water abstraction/contamination \\
\hline Flood defence & Building flood walls, embankments \\
\hline Coastal defence & Building walls, redirecting flow \\
\hline Navigation & $\begin{array}{c}\text { Straightening, widening deepening of channel, } \\
\text { dredging }\end{array}$ \\
\hline Recreation & Building structure e.g. piers, jetties, boat slipways \\
\hline
\end{tabular}




\section{Pressures of Hydro-morphological Changes on BQEs and PCQEs}

Changes in hydro-morphology of water bodies due to pressures from human activities or the effects of climate change, especially extremes described above places pressures ecological systems (Friberg, 2014). While extreme events directly impact on quality elements and on the ability of water bodies to reach good ecological status, any changes in the hydro-morphological quality elements may affect the others quality elements (BQE and PCQE) in negative ways. Not only do hydro-morphological alterations have direct impacts on fish, macroinvertebrates, and macrophyte, they can cause changes in water temperature and reduce the chemical status of water bodies (Reynard, 2010; Villeneuve et al., 2018).

Hydro-morphological degradation has different pressures on different organisms. While macroinvertebrates, fishes, and macrophytes responded remarkably to degradation, diatoms did not respond to the changes in the hydromorphology (Hering et al., 2006). Villeneuve et al. (2018) also found that nutrient and organic matter flows have been affected by changes to hydro-morphology. When rivers experience lower flows especially during a heatwave or low rainfall periods, they are highly sensitive to nutrient and pollution as the dilution of chemicals is lowered. In addition to low dilution capacity, higher chemical arrivals from the riparian zones and agricultural areal would also probably increase the challenges to maintain good ecological and chemical status (Herrero et al., 2018; Outram et al., 2014). Also, low river flows reduce the oxygen level in freshwaters and increase the concentration of pollutants. Combined with higher temperatures and more sunlight, it is likely to cause increase eutrophication and algal blooms, which can disrupt the ecosystem balance (Environment Agency, 2018; Herrero et al., 2018; Reynard, 2010). In the future, it is expected that anthropogenic influences will increase the challenges of eutrophication risk because of lower flows and increased water abstraction. Particularly due to the impacts of global warming and less rainfall for the UK (Howden et al., 2009). Even at present, there are many species and habitats under pressures because of low river flows. Lower flows can cause a decrease in the richness of taxonomy because of losing habitat types. Additionally, sediments and reduction of flow velocity have directly or indirectly had negative impacts on the habitat quality of many communities such as invertebrates. When sediments and flow velocity are taken into account together, the impacts of them would be stronger than individual impacts (Elbrecht et al., 2016).

It is found that river temperature is affected by river flow, river regulation, riparian zone, river channel morphology and anthropogenic modifications (Environment Agency, 2007; O’Briain et al., 2017; Orr, Johnson, Wilby et al., 2015; 
Piccolroaz et al., 2018). Also, any changes in air or ground temperatures and hydrological changes have direct impacts on water temperatures affected by the size of riparian vegetation that provides the shade for cooling the areas including river and riparian ecosystems. It is known that density, viscosity, solubility, and chemical reaction rates, called physical characteristics, are highly vulnerable to water temperature changes. In lowland river areas, it is expected that the decrease in dissolved oxygen concertation will be observed because of warmer temperatures and droughts. Therefore, it is possible to say that overall, water temperature is highly linked to water quality. Studies show that increase in air temperature caused warmer water bodies has resulted in the decrease of dissolved oxygen concertation, and increase on biochemical oxygen demand and suspended solids (Acreman et al., 2009; Bauwens et al., 2013; Cox and Whitehead, 2009; Kalny et al., 2017; The Secretary of State, 2015). On the other hand, similar to impacts of water temperature on PCQEs, invertebrates, and most communities and species in freshwater ecosystems may be affected. Freshwater species' growth rate, distribution, and reproduction are also changed by temperature variations. Recently, the water temperature has reached the lateral levels for some species in the northern part of England (Environment Agency, 2018; O’Briain et al., 2017).

\section{Future Implications of the WFD}

There is no doubt that the changes in the climate system will affect the planned improvement of the quality and management of water bodies. All member states have a responsibility under the WFD to have good status or higher in their water bodies in order to protect and improve aquatic systems across Europe by 2027. In order to achieve all objectives of the WFD, it is essential to integrate with other key policies such as urban planning, flooding, climate and energy policies. For member states, including the UK. To attain a good status in all water bodies, the most important factor is to have effective environmental management. As extensions have been applied to members in the 1st six-year plan, it would be good to consider any extensions where natural conditions such as unexpected extremes do not allow water systems to improve in time (Carvalho, Mackay, Cristina, et al., 2019). Poor links between stressors and impacts on the ecosystem have been one of the weaknesses of the WFD. In the assessment scheme, there are lots of identification of the impacts of BQEs compared to other quality elements. For the hydro-morphological pressures, in contrast, there is not enough identification, with few exceptions. Also, as discussed in previous sections, there is a possibility that across Europe, in the future we may need to live under conditions of more intense and extreme weather events, and at best weather conditions that be equal to today's extreme conditions. The changes in weather patterns are of growing concern and may cause a delay in the 
implication of WFD in the UK. One of the main reasons for failing to achieve objectives of the WFD is the hydro-morphological degradation of water bodies which is a key part towards the understanding of the impacts, changes and actions for the improvement of quality elements (England and Gurnell, 2016; González del Tánago et al., 2016). Hydro-morphological degradation and other pressures such as nutrient enrichment have the potential to get worse in the 2050s and this poses a major challenge for the objectives of the WFD. Planning on mitigation measures under the sustainable and cost-effective management of the WFD have become key elements of member state policy (Henriques et al., 2015).

Most WFD assessment methods have generally focussed on single stressors instead of multiple factorial stressors. However, almost half of the surface waters are under the stress of multiple factors. Inadequate consideration of all factors including climatic and extreme event considerations would cause any implementation measures to be insufficient and underestimate some serious problems in water bodies. While the management plans including single stressors are the best way to show progress in short time periods with quick improvements, more complex situations including multiple stressors need to be considered carefully within the long term planning for better management plan (Carvalho et al., 2019a)

In terms of cost benefit implication, in the 1st six-year RBMP, it was indicated that if all (or 70\%) of European Water Bodies (WBs) were in Good Ecological Status by 2015, the average benefit would have been around 20 billion $€$ or 10.9 billion $€$ per year, respectively (Mattheiß et al., 2012). However, natural conditions and the problems in the implementation of measures have made it difficult for most member states to achieve the aims of the WFD. It is expected that the climate change will modify future precipitation, temperature and extreme events, which will put extra pressures on WFD implications, and it will cost more than before to mitigate effects not only for the UK but also for the rest of Europe (Watts et al., 2015).

Extreme weather events and climate change as a whole are expected to present significant challenges to WFD implementation in Europe and the UK. Member states need to adapt to changes in the climate and to protect ecosystems if GHG emissions cannot be reduced to acceptable levels. Various sources (Carvalho, Mackay, Cardoso et al., 2019) have provided recommendations in terms of three main topics: 
(1) monitoring and assessment: Requires effective communications towards effective communication as well as the incorporation of innovative and monitoring and assessment tools

(2) management: target measures to reduce major stressors

(3) policy integration: Integrate policy with other sectors, including agriculture and urban development

\section{Conclusion}

It is evident that with climate change, extreme events have started to be more intense and frequent since the late $20^{\text {th }}$ century. These events are forecast to have negative impacts on the environment. One of the effects is the expected changes to surface waters, including hydro-morphological changes which this study aimed to assess, that has been conducted in very few studies before. With the assessment of the observation and projection data, it is found that extreme events such as floods and heatwaves have affected river systems throughout the United Kingdom. Moreover, human activities such as building dams or providing protection from floods, and water abstraction practices, especially during heatwaves and droughts have negative impacts on river hydro-morphology.

These and other stressors can have significant and serious effects on river systems, but also other indirect stressors may exacerbate these impacts. Changes in the hydro-morphology of a water body can cause changes such as the increase in water temperature, reducing fish, macroinvertebrates and macrophyte and therefore negatively impact the BQEs and PCQEs. As the WFD requires all members to have good ecological status in all surface waters, the effects of extreme events on the hydro-morphological changes, which also cause changes in the other quality elements, affect the implementation of the WFD.

In order to solve these problems, some actions should be taken immediately to mitigate these events. Regulations and directives such as the WFD related to the improvement of water bodies must be accompanied by climate changes projections and policies. Additionally, instead of focussing on single stressors, multiple stressors should be studied to understand and to propose solutions for more complex changes in river systems. Human activities such as engineering works and restorations in rivers should be considered under the aim of the WFD and other policies related to water quality. Finally, all members should pay more attention to and be transparent on sharing and accessing data, and cooperation. 


\section{Acknowledgement}

This study was supported by The Ministry of Education and was constituted from the MSc thesis titled "How Do Extreme Weather Events Have Pressures on River Hydro-Morphological Quality Elements, and How Do These Lead to the Problem in the Implementation of the Water Framework Directive in the UK?" at Brunel University London. 


\section{References}

Acreman, M., Aldrick, J., Binnie, C., Black, A., Cowx, I., Dawson, H., Dunbar, M., Extence, C., Hannaford, J., Harby, A., Holmes, N., Jarritt, N., Old, G., Peirson, G., Webb, J., \& Wood, P. (2009). Environmental flows from dams: the water framework directive. Proceedings of the Institution of Civil Engineers - Engineering Sustainability, 162(1), 13-22. https://doi.org/10.1680/ensu.2009.162.1.13

Adger, W. N., \& Brown, K. (1993). A UK greenhouse gas inventory: On estimating anthropogenic and natural sources and sinks. Ambio (Journal of the Human Environment, Research and Management), 22(8), 509-517.

Arnell, N. W. (2003). Relative effects of multi-decadal climatic variability and changes in the mean and variability of climate due to global warming: Future streamflows in Britain. Journal of Hydrology, 270(3-4), 195-213. https://doi.org/10.1016/S0022-1694(02)00288-3

Bauwens, A., Sohier, C., \& Degré, A. (2013). Impacts of climate change on hydrological regimes and water resources management in the Meuse catchment. A review. Biotechnology, Agronomy and Society and Environment, 17(1), 76-86.

Biggs, E. M., \& Atkinson, P. M. (2011). A characterisation of climate variability and trends in hydrological extremes in the Severn Uplands. International Journal of Climatology, 31(11), 1634-1652. https://doi.org/10.1002/joc.2176

Black, A. R., Rowan, J. S., Duck, R. W., Bragg, O. M., \& Clelland, B. E. (2005). DHRAM: A method for classifying river flow regime alterations for the EC Water Framework Directive. Aquatic Conservation: Marine and Freshwater Ecosystems, 15(5), 427-446. https://doi.org/10.1002/aqc.707

Boardman, J. (2015). Extreme rainfall and its impact on cultivated landscapes with particular reference to Britain. Earth Surface Processes and Landforms, 40(15), 2121-2130. https://doi.org/10.1002/esp.3792

Bower, D., Hannah, D. M., \& McGregor, G. R. (2004). Techniques for assessing the climatic sensitivity of river flow regimes. Hydrological Processes, 18(13), 2515-2543. https://doi.org/10.1002/hyp.1479

Brown, P., Broomfield, M., Cardenas, L., Choudrie, S., Jones, L., Karagianni, E., Passant, N., Thistlethwaite, G., Thomson, A., Turtle, L., \& Wakeling, D. (2019). UK Greenhouse Gas Inventory 1990 to 2017: Annual Report for submission under the Framework Convention on Climate Change. Department for Business, Energy \& Industrial Strategy. https://ukair.defra.gov.uk/assets/documents/reports/cat07/1905151122_ukghgi-90-17_Main_Issue_2_ final.pdf

Burt, T., Boardman, J., Foster, I., \& Howden, N. (2015). More rain, less soil: Long-term changes in rainfall intensity with climate change. Earth Surface Processes and Landforms, 41(4), 563-566. https://doi.org/10.1002/esp.3868

Capon, S. J., Chambers, L. E., Mac Nally, R., Naiman, R. J., Davies, P., Marshall, N., Pittock, J., Reid, M., Capon, T., Douglas, M., Catford, J., Baldwin, D. S., Stewardson, M., Roberts, J., Parsons, M., \& Williams, S. E. (2013). Riparian Ecosystems in the 21st Century: Hotspots for Climate Change Adaptation? Ecosystems, 16(3), 359-381. https://doi.org/10.1007/s10021-0139656-1 
Carling, P. A. (2013). Freshwater megaflood sedimentation: What can we learn about generic processes? Earth-Science Reviews, 125, 87-113. https://doi.org/10.1016 /j.earscirev. 2013.06.002

Carvalho, L., Mackay, E. B., Cardoso, A. C., Baattrup-Pedersen, A., Birk, S., Blackstock, K. L., Borics, G., Borja, A., Feld, C. K., Ferreira, M. T., Globevnik, L., Grizzetti, B., Hendry, S., Hering, D., Kelly, M., Langaas, S., Meissner, K., Panagopoulos, Y., Penning, E., ... Solheim, A. L. (2019). Protecting and restoring Europe's waters: An analysis of the future development needs of the Water Framework Directive. In Science of the Total Environment (Vol. 658). The Authors. https://doi.org/10.1016/j.scitotenv.2018.12.255

Carvalho, L., Mackay, E. B., Cristina, A., Baattrup-pedersen, A., Birk, S., Blackstock, K. L., Borics, G., Borja, A., Feld, C. K., Teresa, M., Globevnik, L., Grizzetti, B., Hendry, S., Hering, D., Kelly, M., Langaas, S., Meissner, K., Panagopoulos, Y., Penning, E., ... Lyche, A. (2019). Science of the Total Environment Protecting and restoring Europe's waters: An analysis of the future development needs of the Water Framework Directive. In Science of the Total Environment (Vol. 658). The Authors. https://doi.org/10.1016/j.scitotenv.2018.12.255

Colas, F., Baudoin, J. M., Gob, F., Tamisier, V., Valette, L., Kreutzenberger, K., Lambrigot, D., \& Chauvet, E. (2017). Scale dependency in the hydromorphological control of a stream ecosystem functioning. Water Research, 115, 60-73. https://doi.org/10.1016/j.watres.2017.01.061

Cox, B. A., \& Whitehead, P. G. (2009). Impacts of climate change scenarios on dissolved oxygen in the River Thames, UK. Hydrology Research, 40(2-3), 138-152. https://doi.org/10.2166/nh.2009.096

Death, R. G., Fuller, I. C., \& Macklin, M. G. (2015). Resetting the river template: The potential for climate-related extreme floods to transform river geomorphology and ecology. Freshwater Biology, 60(12), 2477-2496. https://doi.org/10.1111/fwb.12639

Department for Environment, Food \& Rural Affairs. (2006). WFD Expert Assessment of Flood Management Impacts.

Department for Environment, Food \& Rural Affairs. (2009). WFD Expert Assessment of Flood Management Impacts, $R \& D$ Technical Report FD2609/TR. http://webcache. googleusercontent.com/search?q=cache:IIbmnToLyWEJ:sciencesearch.defra.gov.uk/Docu ment.aspx\%3FDocument\%3DFD2609_8516_ABS.pdf $+\& c d=2 \& h l=t r \& c t=c l n k \& g l=t r$

Dixon, H., Lawler, D. M., \& Shamseldin, A. Y. (2006). Streamflow trends in western Britain. Geophysical Research Letters, 33(19). https://doi.org/10.1029/2006GL027325

Elbrecht, V., Beermann, A. J., Goessler, G., Neumann, J., Tollrian, R., Wagner, R., Wlecklik, A., Piggott, J. J., Matthaei, C. D., \& Leese, F. (2016). Multiple-stressor effects on stream invertebrates: A mesocosm experiment manipulating nutrients, fine sediment and flow velocity. Freshwater Biology, 61(4), 362-375. https://doi.org/10.1111/fwb.12713

Emma, H. B. (2018). Climate change impacts and adaptation. Environment Agency. https://assets.publishing.service.gov.uk/government/uploads/system/uploads/attachment_d ata/file/758983/Climate_change_impacts_and_adaptation.pdf

England, J., \& Gurnell, A. M. (2016). Incorporating catchment to reach scale processes into hydromorphological assessment in the UK. Water and Environment Journal, 30(1-2), 22-30. https://doi.org/10.1111/wej.12172 
Environment Agency. (2006). Incorporating climate change in river typologies for the Water Framework Directive.

Environment Agency. (2007). Climate change impacts and water temperature.

Environment Agency. (2018). Climate change impacts and adaptation Chair's foreword.

EU Water Framework Directive 2000/60/EC. (2000). Directive 2000/60/Ec Of The European Parliament And Of The Council of 23 October 2000 establishing a framework for Community action in the field of water policy. Official Journal of European Communication. https://doi.org/10.1039/ap9842100196

European Environment Agency. (2018). European waters assessment of status and pressures 2018 (Issue 7).

Feld, C. K., de Bello, F., \& Dolédec, S. (2014). Biodiversity of traits and species both show weak responses to hydromorphological alteration in lowland river macroinvertebrates. Freshwater Biology, 59(2), 233-248. https://doi.org/10.1111/fwb.12260

Fernandes, M. R., Segurado, P., Jauch, E., \& Ferreira, M. T. (2016). Riparian responses to extreme climate and land-use change scenarios. Science of the Total Environment, 569-570, 145-158. https://doi.org/10.1016/j.scitotenv.2016.06.099

Field, C.B., Barros,V., Stocker,T. F., Qin, D., Dokken, D. J., \& Ebi, K.L. (2012). Managing the Risks of Extreme Events and Disasters to Advance Climate Change Adaptation. https://doi.org/10.1596/978-0-8213-8845-7

Friberg, N. (2014). Impacts and indicators of change in lotic ecosystems. Wiley Interdisciplinary Reviews: Water, 1(6), 513-531. https://doi.org/10.1002/wat2.1040

Garssen, A. G., Verhoeven, J. T. A., \& Soons, M. B. (2014). Effects of climate-induced increases in summer drought on riparian plant species: A meta-analysis. Freshwater Biology, 59(5), 10521063. https://doi.org/10.1111/fwb.12328

Giakoumis, T., \& Voulvoulis, N. (2019). Water Framework Directive programmes of measures: Lessons from the 1st planning cycle of a catchment in England. Science of the Total Environment, 668, 903-916. https://doi.org/10.1016/j.scitotenv.2019.01.405

González del Tánago, M., Gurnell, A. M., Belletti, B., \& García de Jalón, D. (2016). Indicators of river system hydromorphological character and dynamics: understanding current conditions and guiding sustainable river management. Aquatic Sciences, 78(1), 35-55. https://doi.org/10.1007/s00027-015-0429-0

Guan, M., Carrivick, J. L., Wright, N. G., Sleigh, P. A., \& Staines, K. E. H. (2016). Quantifying the combined effects of multiple extreme floods on river channel geometry and on flood hazards. Journal of Hydrology, 538, 256-268. https://doi.org/10.1016/j.jhydrol.2016.04.004

Guillod, B. P., Jones, R. G., Bowery, A., Haustein, K., Massey, N. R., Mitchell, D. M., Otto, F. E. L., Sparrow, S. N., Uhe, P., Wallom, D. C. H., Wilson, S., \& Allen, M. R. (2017). Weather@home 2: Validation of an improved global-regional climate modelling system. Geoscientific Model Development, 10(5), 1849-1872. https://doi.org/10.5194/gmd-10-1849-2017

Hannaford, J., \& Buys, G. (2012). Trends in seasonal river flow regimes in the UK. Journal of Hydrology, 475, 158-174. https://doi.org/10.1016/j.jhydrol.2012.09.044 
Hannaford, Jamie. (2015). Climate-driven changes in UK river flows: A review of the evidence. Progress in Physical Geography, 39(1), 29-48. https://doi.org/10.1177/0309133314536755

Hauer, C., \& Habersack, H. (2009). Morphodynamics of a 1000-year flood in the Kamp River, Austria, and impacts on floodplain morphology. Earth Surface Processes and Landforms, 34, 654-682. https://doi.org/10.1002/esp

Hawkins, E. (2019). Show Your Stripes. https://showyourstripes.info/

Henriques, C., Garnett, K., Weatherhead, E. K., Lickorish, F. A., Forrow, D., \& Delgado, J. (2015). The future water environment - Using scenarios to explore the significant water management challenges in England and Wales to 2050. Science of the Total Environment, 512-513, 381-396. https://doi.org/10.1016/j.scitotenv.2014.12.047

Hering, D., Johnson, R. K., Kramm, S., Schmutz, S., Szoszkiewicz, K., \& Verdonschot, P. F. M. (2006). Assessment of European streams with diatoms, macrophytes, macroinvertebrates and fish: A comparative metric-based analysis of organism response to stress. Freshwater Biology, 51(9), 1757-1785. https://doi.org/10.1111/j.1365-2427.2006.01610.x

Herrero, A., Gutiérrez-Cánovas, C., Vigiak, O., Lutz, S., Kumar, R., Gampe, D., Huber-García, V., Ludwig, R., Batalla, R., \& Sabater, S. (2018). Multiple stressor effects on biological quality elements in the Ebro River: Present diagnosis and predicted responses. Science of the Total Environment, 630, 1608-1618. https://doi.org/10.1016/j.scitotenv.2018.02.032

Hooke, J. (2006). Hydromorphological adjustment in meandering river systems and the role of flood events. IAHS-AISH Publication, July, 127-135. https://iahs.info/uploads/dms/13542.20-127135-10-306-Hooke.pdf

Howden, N. J. K., Bowes, M. J., Clark, A. D. J., Humphries, N., \& Neal, C. (2009). Water quality, nutrients and the European union's Water Framework Directive in a lowland agricultural region: Suffolk, south-east England. Science of the Total Environment, 407(8), 2966-2979. https://doi.org/10.1016/j.scitotenv.2008.12.040

Ilnicki, P., Górecki, K., Grzybowski, M., Krzemińska, A., Lewandowski, P., \& Sojka, M. (2010). Ecological quality classes of river hydromorphology in Poland. Journal of Water and Land Development, 14(1), 15-27. https://doi.org/10.2478/v10025-011-0002-8

Intergovernmental Panel on Climte Change. (2013). Climate Change 2013: The Physical Science Basis. Contribution of Working Group I to the Fifth Assessment Report of the Intergovernmental Panel on Climate Change. https://doi.org/10.1017/ CBO9781107415324.Summary

Intergovernmental Panel on Climte Change. (2014). Climate Change 2014: Synthesis Report. Contribution of Working Groups I, II and III to the Fifth Assessment Report of the Intergovernmental Panel on Climate Change [Core Writing Team, R.K. Pachauri and L.A. Meyer (eds.). https://doi.org/10.1017/CBO9781107415324

Jenkins, G. J., Perry, M. C., \& Prior, M. J. (2008). The climate of the UK and recent trends. In Met Office Hadley Center. https://ukcip.ouce.ox.ac.uk/wp-content/PDFs/UKCP09_Trends.pdf

Johnston, J. M., Barber, M. C., Wolfe, K., Galvin, M., Cyterski, M., \& Parmar, R. (2017). An integrated ecological modeling system for assessing impacts of multiple stressors on stream and riverine ecosystem services within river basins. Ecological Modelling, 354, 104-114. https://doi.org/10.1016/j.ecolmodel.2017.03.021 
Kalny, G., Laaha, G., Melcher, A., Trimmel, H., Weihs, P., \& Rauch, H. P. (2017). The influence of riparian vegetation shading on water temperature during low flow conditions in a medium sized river. Knowledge and Management of Aquatic Ecosystems, 418. https://doi.org/10.1051//kmae/2016037

Karoly, D. J., \& Stott, P. A. (2006). Anthropogenic warming of central England temperature. Atmospheric Science Letters, 7(September), 81-85. https://doi.org/10.1002/asl.136

Keesstra, S. D., Kondrlova, E., Czajka, A., Seeger, M., \& Maroulis, J. (2012). Assessing riparian zone impacts on water and sediment movement: A new approach. Netherlands Journal of Geosciences, 91(1-2), 245-255. https://doi.org/10.1017/S0016774600001633

Kendon, M., McCarthy, M., \& Jevrejeva, S. (2015). State of the Climate 2014. Met Office Hadley Centre.

https:/www.metoffice.gov.uk/binaries/content/assets/metofficegovuk/pdf/weather/learnabout/uk-past-events/state-of-uk-climate/state-of-the-uk-climate-2014-v3.pdf

Kendon, M., McCarthy, M., Jevrejeva, S., \& Legg, T. (2016). State of the UK Climate 2015. Met Office Hadley Centre. https://www.metoffice.gov.uk/binaries/content/assets /metofficegovuk/pdf/weather/learn-about/uk-past-events/state-of-uk-climate/mo-state-ofuk-climate-2015-v3.pdf \

Kristensen, P., Feher, J., Gaspar, J., Veres, S.Austner, K., Kiss, A., Gobevnik, L., Peterlin, M., Kirn, T., Stein, U., Prins, T., Spiteri, C., Laukkonen, E., Heiskanen, S.A., Semeradova, S., \& Künitzer, A. (2012) Hydromorphological alterations and pressures in European rivers, lakes, transitional and coastal waters. European Topic Centre on Inland, Coastal and Marine Waters. https://www.eionet.europa.eu/etcs/etc-icm/products/etc-icm-reports/hydromorphologicalalterations-and-pressures-in-european-rivers-lakes-transitional-and-coastal-waters-etcicm-technical-report-2-2012

Lehner, B., Döll, P., Alcamo, J., Henrichs, T., \& Kaspar, F. (2006). Estimating the impact of global change on flood and drought risks in Europe: A continental, integrated analysis. Climatic Change, 75(3), 273-299. https://doi.org/10.1007/s10584-006-6338-4

Lowe, J. A., Bernie, D., Bett, P., Bricheno, L., Brown, S., Calvert, D., Clark, R., Eagle, K., Edwards, T., Fosser, G., Fung, F., Gohar, L., Good, P., Gregory, J., Harris, G., Howard, T., Kaye, N., Kendon, E., Krijnen, J., ... Belcher, S. (2019). UKCP18 Science Overview Report (Vol. 2, Issue March). $\quad$ https://www.metoffice.gov.uk/pub/data/weather/uk/ukcp18/sciencereports/UKCP18-Overview-report.pdf

Mattheiß, V., Paoli, G. De, \& Strosser, P. (2012). Comparative study of pressures and measures in the major river basin management plans in the EU, Task 4b: Costs \& Benefits (Issue September).

Meteorological Office. (2012). Record rainfall - April to July 2012. http://www.metoffice.gov.uk/climate/uk/interesting/april-july2012

Meteorological Office. (2014). Winter storms, December 2013 to January 2014. http://www.metoffice.gov.uk/climate/uk/interesting/2013-decwind

Meteorological Office. (2018a). Summer 2018 - Met Office. Meteorological Office Hadley Centre. https://www.metoffice.gov.uk/climate/uk/summaries/2018/summer 
Meteorological Office. (2018b). UK actual and anomaly maps - Met Office. Meteorological Office Hadley Centre. https://www.metoffice.gov.uk/climate/uk/summaries/anomacts

Meteorological Office. (2019). Met Office Hadley Centre Observations Datasets. Meteorological Office Hadley Centre. http://hadobs.metoffice.com/hadcrut3/diagnostics/comparison.html

Mürle, U., Ortlepp, J., \& Zahner, M. (2003). Effects of experimental flooding on riverine morphology, structure and riparian vegetation: The River Spöl, Swiss National Park. Aquatic Sciences, 65(3), 191-198. https://doi.org/10.1007/s00027-003-0665-6

Nones, M., Gerstgraser, C., \& Wharton, G. (2017). Consideration of hydromorphology and sediment in the implementation of the EU water framework and floods directives: a comparative analysis of selected EU member states. Water and Environment Journal, 31(3), 324-329. https://doi.org/10.1111/wej.12247

Nováky, B., \& Bálint, G. (2013). Shifts and Modification of the Hydrological Regime Under Climate Change in Hungary. In B. R. Singh (Eds.), Climate Change: Realities, Impacts Over Ice Cap, Sea level and Risks (pp.163-190). InTech. http://dx.doi.org/10.5772/54768

Natural Environment Research Council's Centre for Ecology \& Hydrology. (2020). Monthly Hydrological Summaries, National River Flow Archive. https://nrfa.ceh.ac.uk/monthlyhydrological-summary-uk

O'Briain, R. (2019). Climate change and European rivers: An eco- hydromorphological perspective. Ecohydrology, January, e2099. https://doi.org/10.1002/eco.2099

O’Briain, R., Shephard, S., \& Coghlan, B. (2017). River reaches with impaired riparian tree cover and channel morphology have reduced thermal resilience. Ecohydrology, 10(8), 1-9. https://doi.org/10.1002/eco.1890

Orr, H. G., Johnson, M. F., Wilby, R. L., Hatton-Ellis, T., \& Broadmeadow, S. (2015). What else do managers need to know about warming rivers? A United Kingdom perspective. Wiley Interdisciplinary Reviews: Water, 2(2), 55-64. https://doi.org/10.1002/wat2.1062

Orr, H. G., Simpson, G. L., des Clers, S., Watts, G., Hughes, M., Hannaford, J., Dunbar, M. J., Laizé, C. L. R., Wilby, R. L., Battarbee, R. W., \& Evans, R. (2015). Detecting changing river temperatures in England and Wales. Hydrological Processes, 29(5), 752-766. https://doi.org/10.1002/hyp.10181

Outram, F. N., Lloyd, C. E. M., Jonczyk, J., McW. H. Benskin, C., Grant, F., Perks, M. T., Deasy, C., Burke, S. P., Collins, A. L., Freer, J., Haygarth, P. M., Hiscock, K. M., Johnes, P. J., \& Lovett, A. L. (2014). High-frequency monitoring of nitrogen and phosphorus response in three rural catchments to the end of the 2011-2012 drought in England. Hydrology and Earth System Sciences, 18(9), 3429-3448. https://doi.org/10.5194/hess-18-3429-2014

Phillips, J. D. (2002). Geomorphic impacts of flash flooding in a forested headwater basin. Journal of Hydrology, 269(3-4), 236-250. https://doi.org/10.1016/S0022-1694(02)00280-9

Piccolroaz, S., Toffolon, M., Robinson, C. T., \& Siviglia, A. (2018). Exploring and quantifying river thermal response to heatwaves. Water (Switzerland), 10(8), 1-18. https://doi.org/10.3390/w10081098

Poff, N. L., \& Zimmerman, J. K. H. (2010). Ecological responses to altered flow regimes: A literature review to inform the science and management of environmental flows. Freshwater Biology, 55(1), 194-205. https://doi.org/10.1111/j.1365-2427.2009.02272.x 
Ren, F. M., Trewin, B., Brunet, M., Dushmanta, P., Walter, A., Baddour, O., \& Korber, M. (2018). A research progress review on regional extreme events. Advances in Climate Change Research, 9(3), 161-169. https://doi.org/10.1016/j.accre.2018.08.001

Reynard, N. (2010). The Water Resources Sector (Phase 1 report to the Climate Change Risk Assessment). Centre for Ecology \& Hydrology. http://nora.nerc.ac.uk /id/eprint/10272/1/N010272RE.pdf

Rinaldi, M., Surian, N., Comiti, F., \& Bussettini, M. (2013). A method for the assessment and analysis of the hydromorphological condition of Italian streams: The Morphological Quality Index (MQI). Geomorphology, 180-181, 96-108. https://doi.org/10.1016/j.geomorph.2012.09.009

Rivaes, R. P., Rodríguez-González, P. M., Ferreira, M. T., Pinheiro, A. N., Politti, E., Egger, G., García-Arias, A., \& Francés, F. (2014). Modeling the evolution of riparian woodlands facing climate change in three european rivers with contrasting flow regimes. PLoS ONE, 9(10). https://doi.org/10.1371/journal.pone.0110200

Rivaes, R., Rodríguez-González, P. M., Albuquerque, A., Pinheiro, A. N., Egger, G., \& Ferreira, M. T. (2013). Riparian vegetation responses to altered flow regimes driven by climate change in Mediterranean rivers. Ecohydrology, 6(3), 413-424. https://doi.org/10.1002/eco.1287

Romero, I., Pachés, M., Martínez-Guijarro, R., \& Ferrer, J. (2013). Glophymed: An index to establish the ecological status for the Water Framework Directive based on phytoplankton in coastal waters. Marine Pollution Bulletin, 75(1-2), 218-223. https://doi.org/10.1016/j.marpolbul.2013.07.028

Shuker, J. L., Moggridge, H. L., \& Gurnell, A. M. (2015). Assessment of hydromorphology following restoration measures in heavily modified rivers: Illustrating the potential contribution of the Urban River Survey to Water Framework Directive investigations. Area, 47(4), 396-407. https://doi.org/10.1111/area.12185

The Secretary of State. (2015). The Water Framework Directive (Standards and Classification) Directions (England and Wales) 2015. http://www.legislation.gov.uk/uksi/2015/1623/ pdfs/uksiod_20151623_en_auto.pdf

UK Climate Change Risk Assessment. (2012). The UK Climate Change Risk Assessment 2012 Evidence Report. https://doi.org/9780108511257

UK Climate Change Risk Assessment. (2017). UK Climate Change Risk Assessment 2017: Evidence Report.

UK Climate Projections 18. (2018). Data: Anomalies for probabilistic projections (25km) over UK, 1961-2100. MetOffice. https://ukclimateprojections-ui.metoffice.gov.uk/products

UK Technical Advisory Group. (2003). Guidance on the Morphological Alterations and Pressures and Impacts Analyses.

UK Technical Advisory Group. (2008). UK Environmental Standards and Conditions (Issue April).

Van Rijswick, H. F. M. W., \& Backes, C. W. (2015). Ground Breaking Landmark Case on Environmental Quality Standards?: The Consequences of the cjeu "Weser-judgment" (C-461/13) for Water Policy and Law and Quality Standards in eu Environmental Law. Journal for European Environmental and Planning Law, 12(3-4), 363-377. https://doi.org/10.1163/1876010401204008 
Villeneuve, B., Piffady, J., Valette, L., Souchon, Y., \& Usseglio-Polatera, P. (2018). Direct and indirect effects of multiple stressors on stream invertebrates across watershed, reach and site scales: A structural equation modelling better informing on hydromorphological impacts. Science of the Total Environment, 612, 660-671. https://doi.org/10.1016/j.scitotenv.2017.08.197

Visser-Quinn, A., Beevers, L., Collet, L., Formetta, G., Smith, K., Wanders, N., Thober, S., Pan, M., \& Kumar, R. (2019). Spatio-temporal analysis of compound hydro-hazard extremes across the UK. Advances in Water Resources, 130(May), 77-90. https://doi.org/ 10.1016/j.advwatres.2019.05.019

Wade, S., Sanderson, M., Golding, N., Lowe, J., Betts, R., Reynard, N., Kay, A., Stewart, L., Prudhomme, C., Shaffrey, L., Lloyd-Hughes, B., \& Harvey, B. (2015). Developing $H++$ climate change scenarios for heat waves, droughts, floods, windstorms and cold snaps (Issue October).

Walsh, C. J., Roy, A. H., Feminella, J. W., Cottingham, P. D., Groffman, P. M., \& Morgan, R. P. (2005). The urban stream syndrome: current knowledge and the search for a cure. Journal of the North American Benthological Society, 24(3), 706-723. https://doi.org/10.1899/04-028.1

Watts, G., Battarbee, R. W., Bloomfield, J. P., Crossman, J., Daccache, A., Durance, I., Elliott, J. A., Garner, G., Hannaford, J., Hannah, D. M., Hess, T., Jackson, C. R., Kay, A. L., Kernan, M., Knox, J., Mackay, J., Monteith, D. T., Ormerod, S. J., Rance, J., ... Wilby, R. L. (2015). Climate change and water in the UK - past changes and future prospects. Progress in Physical Geography, 39(1), 6-28. https://doi.org/10.1177/0309133314542957

Whitehead, P. G., Wilby, R. L., Battarbee, R. W., Kernan, M., \& Wade, A. J. (2009). A review of the potential impacts of climate change on surface water quality. Hydrological Sciences Journal, 54(1), 101-121. https://doi.org/10.1623/hysj.54.1.101

Yousefi, S., Mirzaee, S., Keesstra, S., Surian, N., Pourghasemi, H. R., Zakizadeh, H. R., \& Tabibian, S. (2018). Effects of an extreme flood on river morphology (case study: Karoon River, Iran). Geomorphology, 304, 30-39. https://doi.org/10.1016/j.geomorph.2017.12.034 


\section{Extended Turkish Abstract (Genişletilmiş Türkçe Özet)}

\section{Așırı Hava Olaylarının Birleșik Krallık Nehir Hidromorfolojisine Etkisi}

18yy ortalarında endüstri devriminin başlangıcından itibaren İngiltere'de fosil yakıt kullanımı önemli ölçüde artmıştır. Fosil yakıtlar; $\mathrm{CO}_{2}, \mathrm{NO}_{x}, \mathrm{SO}_{\mathrm{x}}$ ve diğer sera gazları gibi kirleticiler salan birincil hava kirliliği kaynağıdır. Dünyanın birincil enerji kaynağı olarak fosil yakıtların kullanımı birçok çevresel probleme neden olmaktadır. Özellikle iklim değişikliğinin ana sebeplerinden birisi olan sera gazı etkisi de bu durum ile daha da artmıştır. İklim değişikliği ile birçok hava olayları değişime uğramış ve küresel ölçekte etkili olmaya başlamıştır. Bu değişimlerin başında aşırı hava olaylarının yoğunluğunun ve sıklığının artması gelmektedir. İklim değişikliği ve buna bağlı olarak artan ve sıklaşan aşırı hava olaylarının çevreye ve özellikle su kütleleri üzerine olumsuz etkileri bulunmaktadır.

Su kütleleri üzerine olan etkiler ile başa çıkabilmek için Ekim 2000 tarihinde Avrupa Birliği tarafından Su Çerçeve Direktifi (EU WFD 2000/60/EC) yayımlanmıştır. Direktifin esas amacı üye ülkelerdeki mevcut su kütlelerinin hepsinin iyi duruma getirilmesidir. Su Çerçeve Direktifi (SÇD) AB'deki tüm su kütlelerinin en azından iyi statüye ulaşması için bir hedef belirlemiştir, ancak Avrupa'daki su kütlelerinin neredeyse yarısı şu anda bu standardın altındadır. Yüzey sularında Ekolojik Kalite Durumu Biyolojik Kalite Elementleri, Fiziko-Kimyasal Kalite Elementleri ve Hidromorfolojik Kalite Elementleri ile belirlenir. Hidromorfoloji, nehir ekosistemi için önemli su kalitesi unsurlarından biridir ve Su Çerçeve Direktifine göre, hidromorfolojik kalite elementleri, biyolojik kalite unsurlarını destekleyen kalite unsurlarıdır, bu nedenle ekolojik su kalitesinin kapsamlı bir değerlendirmesi her zaman hidromorfolojik bir değerlendirmeyi içermelidir.

Bu çalışmada, Birleşik Krallık'taki aşıı hava olaylarının nehirlerdeki Hidromorfolojik Kalite Elementleri üzerindeki etkileri, Su Çerçeve Direktif (SÇD)'i uygulamasında sorunlara yol açabilecek diğer baskılarla birlikte değerlendirilmiştir. 20yy başlarından itibaren Birleşik Krallık birçok sıcak hava dalgasının etkisi altında kalmış ve özellikle 1970'lerden sonra sıklaşmaya ve artmaya başlamıştır. 1910'dan 2018'e artan bir trend gösteren sıcak hava dalgası olayları ile ortalama 1C'lik bir artış meydana geldiği görülmüştür. Birleşik Krallık'ta sıcak hava dalgası sıklığı 2000 yılından bu yana artmaya başlamış; kaydedilen en kritik sıcak hava dalgaları 2003, 2006 ve 2018'de meydana gelmiştir. 20yy sonlarında ise sel ve aşırı yağmur olaylarının arttığı görülmüştür. 2008-2017 yılları arasında meydana gelen olaylar 1961-1990 dönemi ile kıyaslandığında \%17'lik bir artış meydana geldiği görülmüştür.

2006 ve 2018 yıllarında Birleşik Krallık’ta yaşanan sıcak hava dalgasında nehir akışlarının önemli bir ölçüde etkilendiği görülmüştür. 2018 Mayıs ayında nehir akışlarının normal olduğu, nadir durumlarda bazı nehirlerin normal altı akışa sahip olduğu, ancak sıcak hava dalgasının pik etkisinin başladığı Temmuz ayında nehir akışlarının \%80'inin normal değerlerinin altına düştüğü tespit edilmiştir. Ağustos ve Eylül aylarında ise sıcak hava dalgasının etkisi azalmış ve nehir akışları normal seviyeye dönmüştür. Ayrıca aşırı yağışların sel ve nehir akışları üzerinde önemli etkileri olduğu görülmüş ve özellikle 2007, 2012 ve 2013-2014 yıllarında meydana gelen aşırı yağışların birçok yıkıcı etkisi olmuştur. İngiltere'nin merkezi ise aşırı yağışlardan dolayı artan nehir akışları için en çok etkilenen bölge olmuştur. Ayrıca aşırı yağışlar sonucunda yaşanan sellerin erozyon, değerli toprak kaybı ve su kaynaklarının kirlenmesi gibi birçok etkisi olmuştur. 
Ayrıca Hidromorfolojik Kalite Elementlerinde meydana gelen bir değişikliğin Biyolojik Kalite Elementleri ile Fiziko-Kimyasal Kalite Elementleri üzerinde etkisi olduğu gözlemlenmiştir. Organik madde akışı ve besin maddelerinin nehirlerde meydana gelen aşırı yoğun akış veya düşük akış olaylarından etkilendiği görülmüştür. Azalan akış ile düşük seyrelme kapasitesi nehir kıyı ekosistemine gelen kimyasalların artmasına ve böylelikle mevcut ekolojik ve kimyasal durumun korumasına engel olmaktadır. Ek olarak nehir suyu sıcaklığının da nehir akışı, kıyı ekosistemi gibi hidromorfolojik etkenlerden etkilendiği görülmüsştür. Nehir kıyı ekosisteminde bulunan bitki örtüsü nehir suyuna gölge sağlayarak su sıcaklığını düşürmektedir. Ancak, sicak hava dalgasi ile birlikte su sıcaklığında meydana gelen artış çözünmüş oksijen konsantrasyonunun düşmesine ve biyokimyasal oksijen ihtiyacının ise artmasına neden olmaktadır.

Su Çerçeve Direktifi'nin uygulanmasında aşırı hava olaylarının ve iklim değişikliğinin önemli ölçüde etkili olması beklenmektedir. Eğer sera gazlarının ve iklim değişikliğinin olumsuz etkileri azaltılmaz veya durdurulamazsa üye ülkelerin bu değişiklere adapte olması gerekmektedir. İzleme, değerlendirme, yönetim ve politika entegrasyonu Su Çerçeve Direktifi’nin değişiklikler ile mücadele için sunulan önerilerdir.

Sonuç olarak, aşırı hava olayların olduğu dönemlerde nehir hidromorfolojisinin özellikle nehir akışları, sedimentleri ve nehir kıyı bölgeleri açısından etkilendiği bulunmuştur. Nehir sistemleri, sırasıyla azalan ya da olağanüstü yüksek akıma sebep olan kuraklık ve yoğun ve şiddetli yağış gibi aşırı hava olaylarından önemli ölçüde etkilenmektedir. Azalan akışlar, sudaki organizmaların yaşam alanlarının kaybına ve balık ölümlerinin artmasına neden olabilir. Artan nehir akışları, sediment dinamiği ve kanallarındaki değişiklikler de dahil olmak üzere nehirlerin hidromorfolojisinde değişikliklere yol açarken, nehirler, baraj inşa etme ve su soyutlamaları gibi aktiviteler de dahil olmak üzere antropojenik hidromorfolojik basınçların olumsuz etkileri altındadır. Buna ek olarak, nehir hidromorfolojisindeki değiş̧ikler su sıcaklığını ve çözünmüş oksijen miktarını arttıran ve böylece Biyolojik Kalite Elementleri ve Fiziko-Kimyasal Kalite Elementlerini indirgeyen başka problemlere neden olabilir. Birleşik Krallık'ta aşırı hava olaylarının yoğunluğunun ve sıklığının artması, Su Çerçeve Direktifi'nin maliyet etkinliği ve sürdürülebilirlik açısından uygulanmasında zorluklara neden olacağına hiç şüphe yoktur. $\mathrm{Bu}$ sorunlarla başa çıkmak ve bunları azaltmak için, iklim değişikliği projeksiyonlarını dikkate alan, su talebini azaltan, suyun mevcudiyetini ve kalitesini iyileştiren, tarımsal ve kentsel arazi kullanım uygulamalarını değiştiren bütüncül bir su politikası gereklidir. 